\title{
Henry VII's Book of Astrology and the Tudor Renaissance*
}

\author{
by Hilary M. CAREY
}

This essay considers the place of astrology at the early Tudor court through an analysis of British Library MS Arundel 66, a manuscript compiled for the use of Henry VII (r. 1485-1509) in the 1490s. It argues that an illustration on fol. 201 depicts King Henry being presented with prognostications by his astrologer, William Parron, with the support of Louis, Duke of Orleans, later King Louis XII of France (r. 1498-1515). It considers the activities of three Tudor astrologer courtiers, William Parron, Lewis of Caerleon, and Richard Fitzjames, who may have commissioned the manuscript, as well as the Fitzjames Zodiac Arch at Merton College, Oxford (1497) and the London Pageants of 1501. It concludes that Arundel 66 reflects the strategic cultural investment in astrology and English prophecy made by the Tudor regime at the time of the marriage negotiations and wedding of Arthur, Prince of Wales and Katherine of Aragon, descendant of Alfonso $X$, the most illustrious medieval patron of the science of the stars.

\section{INTRODUCTION}

B ritish Library MS Arundel 66 is one of the finest of all English medieval and Renaissance scientific manuscripts. ${ }^{1}$ Indeed, John North gave it a broader international significance by suggesting that one item in the collection, a copy of the tables of the Oxford astronomer John Killingworth (d. 1445), was, possibly, "the most sumptuous astronomical tables ever penned." 2 The manuscript has been firmly dated to the year 1490 and, since the nineteenth century, has been associated with Henry VII (r. 1485-1509). On fol. 201 ${ }^{\mathrm{r}}$, the king is depicted enthroned and

"Research funding that enabled visits to the British Library and Merton College, Oxford was provided by the University of Newcastle and the Australian Research Council. I acknowledge the assistance of Wendy Alexander, Timothy Ayers, Monica Azzollini, Charles Burnett, Edward James, Linne Mooney, and Laura Smoller, and the scholarly generosity of anonymous readers of this and earlier versions of this essay. I am also grateful to the Centre for Medieval Studies at the University of York for a visiting professorship, during which the greater part of the essay was drafted. Unless specifically mentioned, all translations are my own.

${ }^{1}$ Notices of the manuscript (regularly updated in the online BL Catalogue of Illuminated Manuscripts) include: Birch and Jenner, 16; Carey, 1992, 106, 202; Page, 2002, 23-24, 26-28, 31; Pattie, 25; McKendrick, Lowden, and Doyle, no. 99 (hereafter cited as Royal Manuscripts); Saxl, Meier, and Bober, 1:89-93; Scott, 1996, 2:364-67; Scott, 2002, 93; Ward, 301-02; Watson, 216; Whitfield, 2001, 45.

${ }^{2}$ North, 1989, 344; see also North, 2004. 
surrounded by his courtiers while he receives astrological prognostications for the coming year with the support of a distinguished nobleman, labeled with the arms of Louis II, Duke of Orleans, later Louis XII, King of France (r. 1498-1515: see figs. 1 and 2). Sophie Page has suggested that this image represents the king as "a significant mover on the world stage with events of widespread impact on his realm: the fertility of the land, warfare and plague." ${ }^{3}$ It also suggests that Henry VII was a ruler who chose to make strategic use of astrology and did so with the full backing of church and state at home and abroad.

Astrology formed an integral part of the Renaissance worldview, albeit one that was hotly debated by intellectuals, scholars, and theologians. ${ }^{4}$ Nevertheless, we know much less about astrology at the Tudor court than elsewhere in Renaissance Europe or at the courts of earlier English kings such as Henry II (r. 1154-89), Edward III (r. 1327-77), Richard II (r. 1377-99), and Henry V (r. 1413-22). ${ }^{5}$ Bernard Capp described late medieval England as an "astrological backwater," but astrology had a place in the cultural landscape of the emerging Tudor dynasty. ${ }^{\circ}$ C. A. J. Armstrong long ago established that Henry VII was a patron of astrology: he was the first English monarch to have employed a court astrologer, the Italian physician William Parron of Piacenza (before 1461-ca. 1503). ${ }^{7}$ Sydney Anglo also demonstrated that astrology had a central role in what was possibly the most significant cultural performance of the king's reign, the Burgundian-style pageants for the entry of Katherine of Aragon (1485-1536) into the City of London on 12 November $1501 .^{8}$ Through a close study of Arundel 66, this essay aims to extend our knowledge of astrology in the Tudor Renaissance, building on the pathbreaking studies by Armstrong and Anglo.

Inevitably, like the vast majority of medieval and Renaissance manuscripts, the exact provenance of Arundel 66 cannot be determined with certainty, nor is it possible to provide a forensic demonstration of connections between this manuscript, patrons such as Fitzjames, astrologer courtiers such as Parron,

${ }^{3}$ Page, 2002, 26, and fig. 18.

${ }^{4}$ For the astrology debate in the fifteenth and sixteenth centuries, see Allen; Garin; Grafton; Smoller; Vanden Broecke.

${ }^{5}$ For astrology at the medieval English court, see Carey, 1992. For elsewhere in Europe, see Azzollini; Boudet, 2006; Garin; Veenstra.

${ }^{6}$ Capp, 18.

${ }^{7}$ Armstrong. All dates and spelling of English names adopted from the Oxford Dictionary of National Biography.

${ }^{8}$ See Anglo, 1963; less completely, Anglo, 1997. For a different interpretation of the pageants, that also recognizes the centrality of astrology to their interpretation, see Kipling, 1977, 72; Kipling, 1981. 


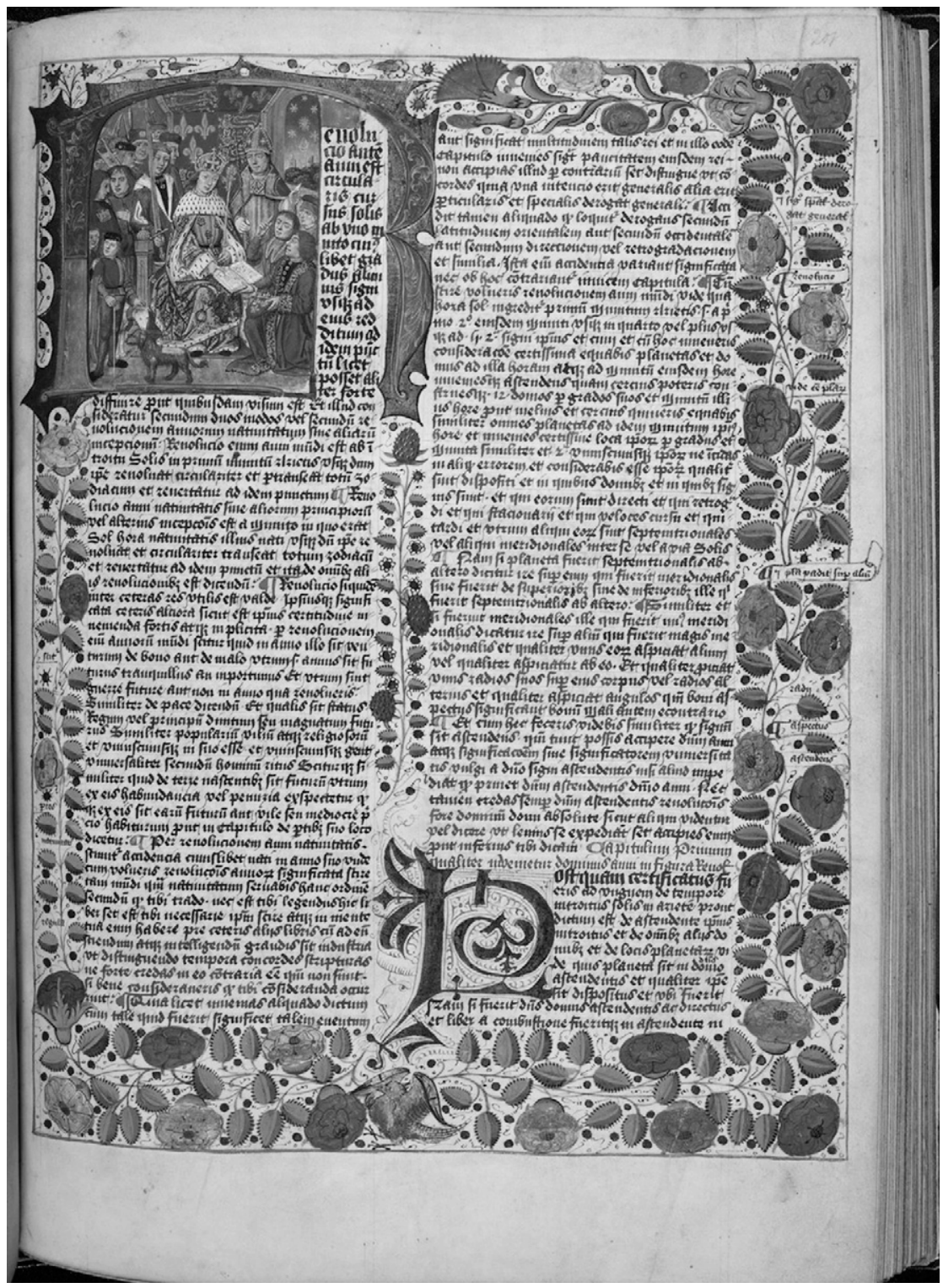

FIGURE 1. Opening folio of Guido Bonatti, Introduction to astrology, bk. 8. MS Arundel 66, fol. 201 ${ }^{\mathrm{r}}$. Courtesy of the British Library Board.

or the London astrological pageants. However, they were all more or less contemporary, they are associated through tendrils of style and patronage, and, when considered together, they reflect a strategic investment in the royal art of astrology that may be associated politically with negotiations 


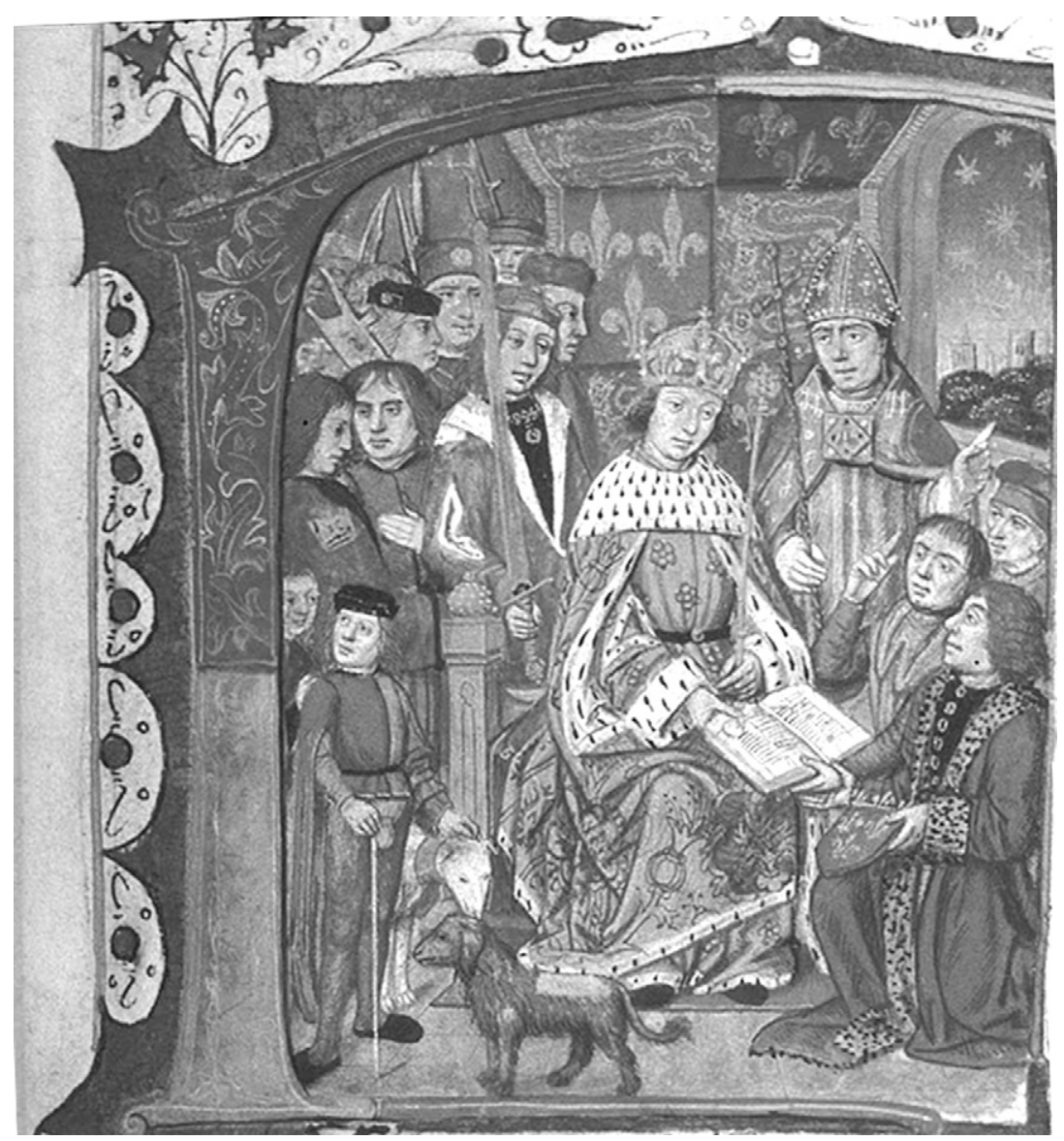

FIGURE 2. Henry VII enthroned and receiving astrological prognostications. Detail of MS Arundel 66, fol. 201 ${ }^{\mathrm{r}}$. Courtesy of the British Library Board.

for the marriage of Arthur, Prince of Wales, and Katherine of Aragon. There are three sections to this analysis: first, a detailed description of Arundel 66 and a review of some earlier accounts of the manuscript and its association with Henry VII; second, a consideration of the evidence for identifying the manuscript's owner, donors, date, and general provenance; third, an account of three courtiers known to have demonstrated a keen interest in astrology, including Parron, the academic and ecclesiastic Richard Fitzjames (d. 1522), and the physician Lewis of Caerleon (d. in or after 1495). It concludes with a consideration of the European Renaissance context for the patronage of astrology and its reflection in pageantry, heraldry, book art, and other cultural productions of the early Tudor court. 


\section{ARUNDEL 66}

Arundel 66 is a complex manuscript that shows a high degree of planning and financial and artistic investment in its execution. ${ }^{9}$ It has seven major components, a number of which were the fruits of original scientific projects completed under the earlier princely patronage of Humphrey, Duke of Gloucester (1390-1447). The first section has the canons and tables for making an almanac by the Merton astronomer John Killingworth. ${ }^{10}$ Second is an illustrated catalogue of the "faces" (facies) of forty-five constellations with their celestial latitudes and longitudes and astrological complexions adjusted for the meridian of Oxford (fols. $33^{\mathrm{r}}-46^{\mathrm{v}}$ ). Third is the Introduction to astrology in ten books by the Italian astrologer Guido Bonatti of Forlì (1223-1300). This takes up almost 200 folios (fols. $\left.48^{\mathrm{r}}-249^{\mathrm{r}}\right)$ and is the longest item in the manuscript. Fourth are canons and tables extracted from the Alfonsine Tables (fols. $250^{\mathrm{r}}-266^{\mathrm{r}}$ ). Fifth is a copy of the Merlin prophecies from Geoffrey of Monmouth's History of the Kings of Britain $\left(\right.$ fol. $267^{\mathrm{r}}$ ). Sixth is the Geomancy of Alpharinus (fols. 269 $-276^{\mathrm{r}}$ ), followed by a set of geomancy tables said to have been compiled for Humphrey, Duke of Gloucester (fols. $277^{\mathrm{v}}-286^{\mathrm{r}}$ ). Finally, there is a short collection of other prophecies by Robert of Bridlington (fols. $288^{\mathrm{r}}-290^{\mathrm{r}}$ ), Birgitta of Sweden (fols. $291^{\mathrm{r}-\mathrm{v}}$ ), Merlin (fol. $291^{\mathrm{r}}$ ), and others.

The manuscript is a careful compilation that provided the technical tools necessary for the practice of judicial astrology, which required astronomical tables adjusted for English use, updated and illustrated tables of the constellations, and a comprehensive astrological textbook. Together they make a striking demonstration of English expertise in both the astronomical and astrological branches of the science of the stars. ${ }^{11}$ The manuscript concludes with a series of robustly English sources that attest to the prophetic and mythic origins of the Tudor dynasty.

${ }^{9}$ See Appendix for a full description of the manuscript. All references to Arundel 66 appear in citations in the text; citations to all other manuscripts appear in the notes.

${ }^{10}$ North, 2004.

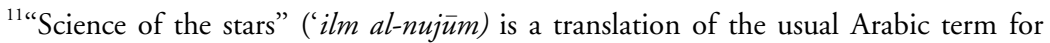
astrology and astronomy, and was traditionally divided into its theoretical and applied branches: astronomy, including the study of instruments and tables, and judicial astrology. The latter was subdivided in turn into introductions, conjunctions, revolutions (including weather prediction), nativities, interrogations, and elections. For the term ' $i l m$ al-nujūm, see Rāshid and Morelon, 1-2. For succinct overviews of medieval Latin astrology and a guide to further specialist reading, see Burnett; Carey, 2010a. For an authoritative synthesis, see Boudet, 2006. 
Although it takes up relatively little space in the manuscript, the last component of Arundel 66 is of particular significance for the light it sheds on interest in English prophecies at the Tudor court, particularly if credence is given to a possible connection with Arthur, Prince of Wales (1486-1502), and the cult of Arthurian Britain that accelerated after Caxton's publication of Malory's King Arthur in 1485. This section includes prophecies and revelations attributed to Robert of Bridlington, Birgitta of Sweden, Merlin, and others. Three of the four authorities cited are English prophets and mystics, while Birgitta of Sweden enjoyed strong support in England, including royal patronage. Robert of Bridlington (ca. 1320-79), also known as John Thwing, was prior of the convent of Augustinian canons at Bridlington. He was celebrated for his saintly life and charity, and also for a series of prophecies attributed to him that were popularized by the commentary of John Erghome. There are at least thirty-seven copies of his prophecies, of which that in Arundel 66 is by far the most luxurious. ${ }^{12}$

The second prophetic work in the manuscript is an extract from the Revelations of Birgitta of Sweden (1303-73). Born into the nobility, Birgitta was celebrated in her lifetime for her visions, which were originally transcribed in Latin and later translated into many languages, including English. ${ }^{13}$ Her fame in England came from one of her revelations concerning the wars between France and England, which she experienced while on pilgrimage to Santiago di Compostella. On her return to Sweden, Birgitta intervened directly to try and halt the conflict by sending an envoy, Bishop Hemming, with copies of her work to present to Pope Clement VI (r. 1342-52) and to the French and English kings in 1347. With these impressive royal and ecclesiastical credentials, this vision circulated independently before being chosen for inclusion in Arundel 66. ${ }^{14}$

Following Birgitta's vision are the Merlin Prophecies from book 7 of Geoffrey of Monmouth's History of the Kings of Britain; this work was probably written in the 1130s and, like Birgitta's, it circulated independently from the main text. ${ }^{15}$ It begins with Geoffrey's dedication to Alexander, Bishop of Lincoln (r. 1123-48), which explains why he translated the Prophecies of Merlin from British, i.e., Welsh, into Latin. It continues with an account of the coming of a red dragon, an image that was applied to the rise

\footnotetext{
${ }^{12}$ Wright. For Bridlington and Erghome, see also Curley, 1980 and 1984; Mayvaert; Rigg.

${ }^{13}$ Holloway.

${ }^{14}$ St. Birgitta of Sweden, 4.104-05. For other manuscript copies of this extract, see Bodleian, Ashmole Roll 26 (olim 27), verso, which has the same incipit.

${ }^{15}$ Reeve; Hammer, 1935 and 1940.
} 
of the British Tudors in the Wars of the Roses. The "red dragon dreadful" (emitting flame) of Cadwalader was appropriated as a central emblem for the Tudor dynasty and was deployed in the banners and badges of Henry VII. ${ }^{16}$ Historians have differed over the extent to which the British tradition of Merlin and his prophecies and the Arthurian legend impacted the coming of age of Prince Arthur. ${ }^{17}$ By including this foundational Tudor prophecy in the context of the other components of Arundel 66, it was instantly elevated to the ranks of the major prophetic and astrological works of the age.

Given these Tudor allusions, it is surprising that, although Arundel 66 has long been admired by art historians, it has not been incorporated into mainstream scholarly analysis of the Tudor court and dynasty. Possibly this is because there has remained some doubt about the connection of the manuscript with Henry VII and about its provenance: unlike other great royal books, it did not remain in the Royal Library, but came by paths unknown into the hands of art collector Thomas Howard (1585-1646), Second Earl of Arundel, who presented it to the Royal Society, which sold it on to the British Museum in 1831. Nevertheless, a connection with Henry VII was asserted as long ago as 1834 in the catalogue description of the Arundel manuscripts by Forshall, who stated that it was "elegantly produced and adorned for the use of Henry VII whose effigy you will find at fol. 201."18 The fullest description of the manuscript remains that by Saxl and Meier, who, like Forshall, thought that it was most likely to have been produced for Henry VII. ${ }^{19}$ Thorndike also refers to this manuscript and its relationship to Henry VII and Duke Humphrey. ${ }^{20}$ Apart from the description in the catalogue of the British Library's December 2011 exhibition of the Royal Library, there is no discussion of the manuscript in any of the recent major accounts of the king, including the entry in the online Oxford Dictionary of National Biography; the historiated initial on fol. $201^{\mathrm{r}}$ is not on the list of likenesses of the king compiled by Gunn. ${ }^{21}$ It is not discussed by Janet Backhouse in her studies of Edward IV and Henry VII as founders of the Royal Library, ${ }^{22}$ nor in Scott's account of the illuminated manuscripts associated with Henry VII and his immediate family. ${ }^{23}$

\footnotetext{
${ }^{16}$ Walden, 78.

${ }^{17}$ This view is dismissed, perhaps too readily, by Anglo, 1992, 52-53. For the interest of Henry VII and Henry VIII in Arthur, see Starkey; Hughes, 307.

${ }^{18}$ Forshall, 14.

${ }^{19}$ Saxl, Meier, and Bober, 1:89-93, plate 79 (fol. 3b).

${ }^{20}$ Thorndike, 4:437.

${ }^{21}$ Royal Manuscripts, no. 99; Gunn, 2004.

${ }^{22}$ Backhouse, 1987 and 1995.

${ }^{23}$ Scott, 2007.
} 
One possible reason for the curious neglect of Arundel 66 is that, as a great illuminated manuscript written in Latin about astronomy, astrology, geomancy, and prophecy, it does not fit the preconceived views that we currently have of the king's character and interests. The most recent biography by Thomas Penn, which makes no reference to Arundel 66, stresses the restless, parsimonious intelligence with which he maintained his grip on power. ${ }^{24}$ According to Alexander, Henry was "a quiet man with an obvious intellectual bent," who loved books and stocked his library at Sheen with volumes in Latin, French, and German. ${ }^{25}$ Since he was not brought up to inherit a throne, he was not fluent in Latin, the language of international affairs, rhetoric, and scholarship, though he knew its value. When he needed to work in Latin, he preferred to engage Frenchmen and Italians preferably ones with humanist training - as diplomats, librarians, secretaries, and tutors.

Art historians have generally supported these views of the king, based on the corpus of his surviving books. According to Scott, Henry VII had no urge toward personal patronage of book artists and was especially dismissive of the homegrown English product. ${ }^{26}$ She argues that, as far as we can tell, he was not very interested in manuscripts and if obliged to spend his own money - he was noted for his thrift - preferred to purchase illuminated versions of printed books. A number of these were acquired from the Parisian publisher Anthoine Vérard, who arranged to have them embellished with the royal arms, heraldic devices, and sometimes special dedications. ${ }^{27}$ The illuminated manuscripts that he happened to possess mostly came into his hands by way of gifts. This argument about Henry's taste for printed books rather than manuscripts has been endorsed in the most recent account of the Royal Library. ${ }^{28}$

Nevertheless, if he was not inclined to commission illuminated manuscripts, there is evidence that Henry VII was prepared to acquire (or remodel) illuminated manuscripts if they could serve as aids in the education of the rising generation, or enhance the cultural prestige of the Tudor regime. Unlike Henry himself, Henry's children were provided with a series of tutors who supplied them with an excellent humanist education that ensured they acquired fluent Latin and French, though there is no sign that

\footnotetext{
${ }^{24}$ For sleighting references to Parron, see Penn, 38, 94.

${ }^{25}$ Alexander, 47.

${ }^{26}$ Scott, 2007.

${ }^{27}$ Winn, 138-53, cited by Stratford and Webber.

${ }^{28}$ Stratford and Webber, 1:214-15.
} 
they were trained in any of the mathematical arts other than music. ${ }^{29}$ As a work of reference, Arundel 66 filled a didactic hole in the royal collection. It provided an exquisitely illustrated set of data for the constellations verified, as it states on fol. $47^{\mathrm{r}}$ : "by the astrologers of Lord Alfonso the illustrious King of Spain and verified in Oxford in the year of the lord 1449 by the astrologers of Humphrey Duke of Gloucester." This work is in effect a celestial atlas, albeit one presented in tabular form, that shows an English prince as a patron of science of the stars in the manner of Alfonso $\mathrm{X}$ of Castile. This was a useful source of national pride at a time when negotiations were in train for a royal marriage between Spain and England.

It also included Killingworth's Oxford tables, which enabled the calculation of an ephemeris, an activity that was the essential precursor to client-based judicial astrology, which up until this time had remained almost entirely restricted to the court and to some academic circles. ${ }^{30}$ North describes them as "tables for producing tables" and regarded them as one of the most distinguished achievements by any of the great Merton calculators. ${ }^{31}$ These astronomical works precede the commodious astrological textbook by Guido Bonatti, the most celebrated of all medieval Italian astrological authorities - something reflected in Dante's decision to place Bonatti in the eighth circle of Hell, where he is pointed out as a representative of those fortunetellers and diviners who presumed to usurp God's omnipotence by seeking knowledge of the future. ${ }^{32}$ We can assume that whoever commissioned Arundel 66 had a higher opinion of Bonatti's respectability than Dante. There is also the geomancy by Alpharinus, a standard work on this subject, which is augmented by Tables and Canons said, like the Killingworth Tables, to have been produced for Humphrey, Duke of Gloucester, the illustrious Lancastrian patron claimed by the Tudors, through Margaret Beaufort, as part of their own rather tenuous royal lineage. ${ }^{33}$

Backhouse's argument about Henry VII's taste in books was challenged by Kathleen Scott, the first scholar to focus attention on Arundel 66, by giving it a prominent place as the final item in her survey of manuscripts illuminated in the British Isles in the fifteenth century. ${ }^{34}$ Scott argued that this manuscript represented the culmination of the late-Gothic illuminated

${ }^{29}$ Carlson, 1991.

${ }^{30}$ For Richard Trewythian, the first English astrologer known to have produced his own ephemeris, see Page, 2001.

${ }^{31}$ North, 2004.

${ }^{32}$ Dante, 210 (Inferno, 20.108).

${ }^{33}$ For geomancy, see Charmasson. For geomancy in the fifteenth century, including early printed editions in Italian, see Thorndike, 4:469-75.

${ }^{34}$ Scott, 1996, 364-67. 
English book, citing its impressive planning, high level of technical execution, and evidence of collaboration between relatively unskilled English artists and a Flemish master illustrator responsible for the presentation miniature. Instead of ignoring or attempting to explain away the royal associations of Arundel 66, she argued that Henry VII not only commissioned this book, but that it provided direct evidence of the elegance of his taste, his discerning interest in astrology, and his sense of fun. She also suggested that it may have been the most lavish and expensive book in the Royal Library. While hesitating to speculate on its cost, she estimated that it exceeded the $£ 23$ we know the king paid his librarian, Quentin Poulet, for the execution of another volume of similar scale.

Nevertheless, Backhouse's suggestion that Arundel 66 reflects Henry VII's personal interests fails to convince. If the royal librarian or another courtier close to King Henry did commission this volume for his use, there is simply no evidence that this was the result of a direct request by the king. On the other hand, the contents, date, and decoration of the manuscript are all compatible with its status as a royal gift by a highly placed courtier who was aware of the king's strategic priorities. As such, we can assume that the manuscript was prepared with the king's cultural sympathies in mind, including a benign attitude toward judicial astrology and a preference for printed books. It will next be suggested that the largest item in Arundel 66, namely Guido Bonatti's Introduction to astrology in ten books, first published in Augsburg in March 1491, is actually a copy of a printed book. To establish this, it must first be shown that the evidence that dates the whole manuscript to 30 June 1490, nine months before this work was first printed, is open to question.

\section{Scribe, Dating, ANd Donor(s)}

One of the few really secure bits of information about Arundel 66 would appear to be the name of its scribe and the date he finished his work. However, this information does not form part of the formal apparatus of the manuscript. Instead, it appears in a hastily scrawled and corrected note that appears on the second of five blank folios (fol. $249^{\mathrm{r}}$ ) between the end of Guido Bonatti's Introduction to astrology and before the extracts from the Alfonsine tables. This reads as follows:

Finitur hic liber Gwuydonis bonacti de forlivio

Anno Christi 149030 die Junij ho ${ }^{\text {ra }} 12 \mathrm{~m}^{\mathrm{a}} 24^{\mathrm{a}}$ per me

Johannem Wellys compositus et renovatus et anno

Henrici regis $7^{\mathrm{i}} .4^{\text {to }}$ pontificatus sanctissimi in Christo patris nostris Innocentij pape $4^{\text {to }} 5^{\text {to }}$ 
This can be translated as "Here ends the book of Guido Bonatti of Forlì, compiled and updated by me John Wellys in the year of Christ 1490, the $30^{\text {th }}$ day of June, the $12^{\text {th }}$ hour and the $24^{\text {th }}$ minute, in the fourth year of the reign of Henry VII, the fifth year of the pontificate of our most holy father in Christ Pope Innocent." Except for the early date, there would appear to be no question that the scribe, "John Wellys," was dependent for his update of the manuscript on the first edition of Guido Bonatti's Introduction to astrology, which was prepared by the master scientific editor Johannes Angelus (or Engel) and printed in Augsburg by Ratdolt on 26 March 1491, six months after "John Wellys" wrote his note to Arundel 66. ${ }^{35}$ The layout and text of the Arundel 66 and Ratdolt editions of Bonatti are almost identical, and both include the very elaborate index, which was mistakenly attributed to Regiomontanus by Symon de Phares (ca. 1440-ca. 1499)..$^{36}$ This is made clearer if two facing pages of the single columns of the printed edition are compared with the double columns of Arundel 66 showing the precise match of the decorated initials (fig. 3). ${ }^{37}$

Of course, it is possible that Arundel 66 or something very like it was the manuscript model for the Ratdolt edition: however, it seems more likely that the reverse was true, or that both used the same heavily marked-up and annotated version of the text prepared by Engel, including the remarkable index. As evidence of this, it might be noted that the text of Bonatti in Arundel 66 has numerous marginal annotations, including diagrams, points of emphasis, and corrections (fig. 4). Either these were the work of Wellys or they were incorporated from the model on which the scribe was dependent. In either case, the scribal note need not refer to the date of the completion of the entire manuscript but simply the terminus ante quem non of one section of it, Guido Bonatti's Introduction to astrology. As for a terminus post quem non, this needs to be extended to 1498, the year Louis became King of France and would no longer be depicted as Duke of Orleans, as he appears on fol. $201^{\mathrm{r}}$ (fig. 2).

As Pearl Kibre has shown, both printed and manuscript books of astrology were frequently found in princely libraries of the fifteenth and sixteenth centuries. ${ }^{38}$ In addition, it was not uncommon for deluxe manuscript copies to be made of printed books. For example, Mellon MS 25, now in

${ }^{35}$ Bonatti, fol. $406^{\mathrm{v}}$. Even with the emendation, the regnal dating is not correct. Innocent VIII was elected on 29 August 1484, slightly less than a year before Henry VII's accession on 22 August 1485 . The date 30 June 1490 fell in the fifth year of Henry's reign and the sixth year of Innocent's pontificate, not the fourth and fifth respectively as the scribe supposed.

${ }^{36}$ Wickersheimer and de Phares, 264.

${ }^{37}$ There are minor divergences between printed and manuscript versions of the text. See the URL listed in the bibliography for Bonatti to compare with Arundel 66.

${ }^{38}$ Kibre, 1946. See also Blume. 


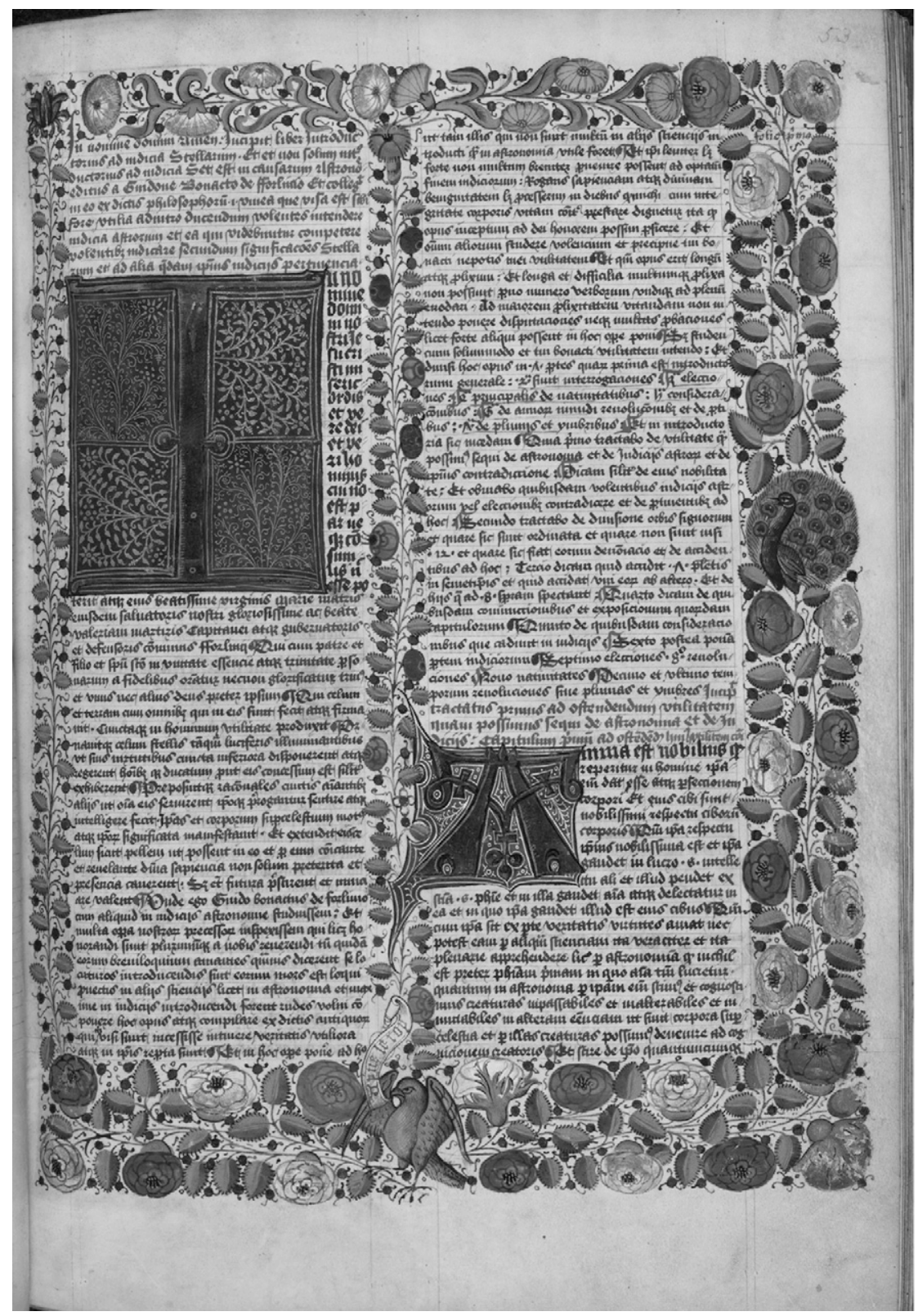

FIGURE 3. Opening folio of Guido Bonatti, Introduction to astrology, MS Arundel 66, fol. $53^{\mathrm{r}}$. Courtesy of the British Library Board. 


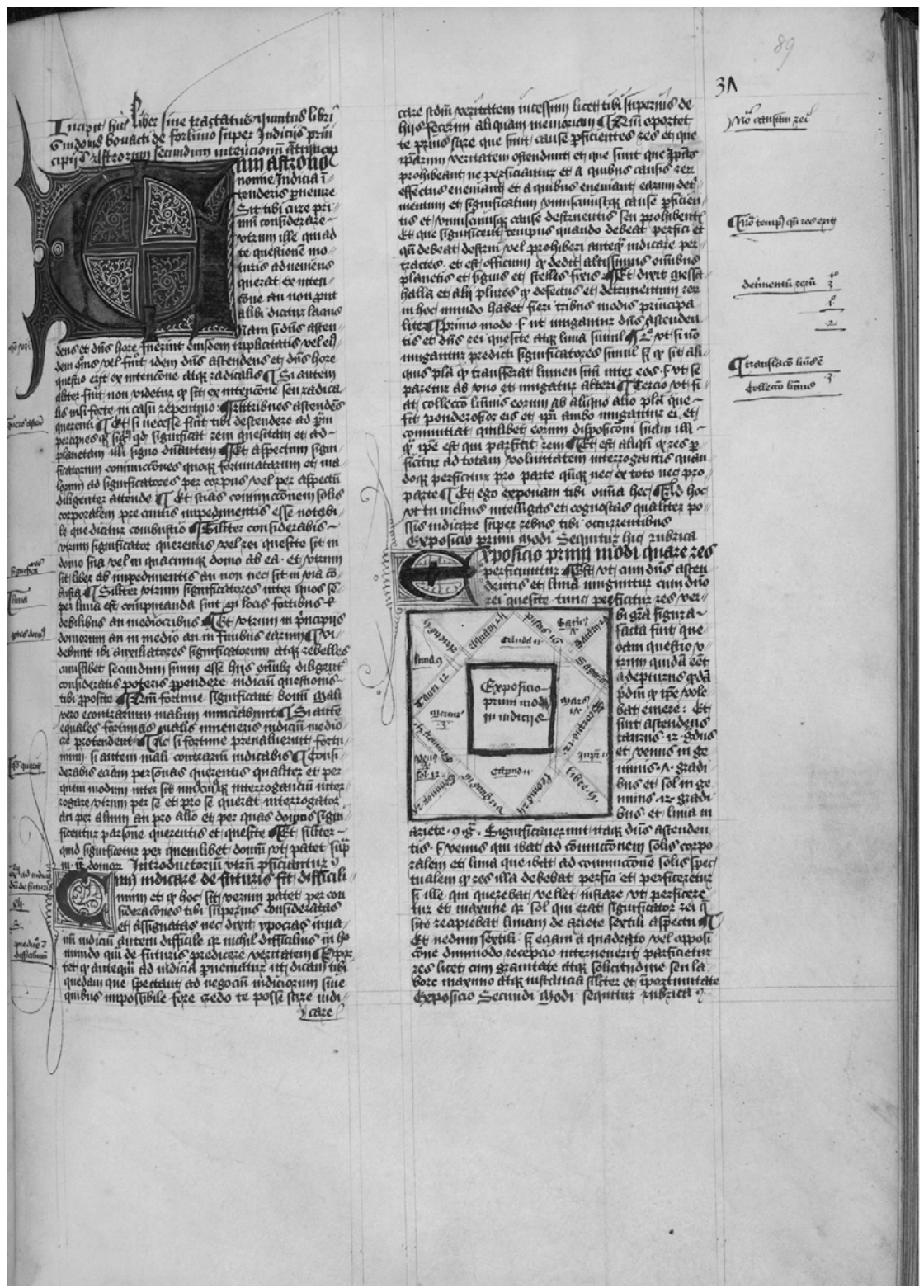

FIGURE 4. Marginal annotations and astrological diagram from Guido Bonatti, Introduction to astrology, bk 6 . Arundel 66, fol. $89^{\mathrm{r}}$. Courtesy of the British Library Board. 
the Beinecke Rare Book and Manuscript Library of Yale University, is an astrological miscellany copied in Northern France or Flanders in a sumptuous style similar to Arundel 66, and that was prepared for an unknown ducal library in about $1505 .{ }^{39}$ It is derived from two early printed editions: Ptolemy's Centiloquium and other texts, published by Locatellus in Venice in 1493; and the Astrolabium planum by Johannes Engel (actually an introduction to astrology), published by Ratdolt at Augsburg in $1488 .{ }^{40}$ Originally based in Venice, the number of astrological works published by Ratdolt increased once the publisher returned to Augsburg, and these were particularly desirable for their high quality illustrations, text, and data. In 1489 Ratdolt began publishing editions of the almanac that were first credited to Marcus Schybbagel (Augsburg, ca. 1486-87) and later to Engel (Augsburg, 1488-89) and Erhard Etzlaub (ca. 1514-15). Arundel 66 was a fine illuminated book produced in an age in which the transition from manuscript to print was well underway.

If Arundel 66 had been conceived as a royal gift, it must then have had a donor. Can we identify who this could have been? First, some general principles. In relation to Valois patrons, Brigitte Buettner notes that typical book donors included writers, secretaries, librarians, and merchants in the book trade. ${ }^{41}$ The same point can be made about book donations and the representations of donors in books known to have been presented to, or commissioned by, royal patrons in England in the same period. ${ }^{42}$ Manuscripts were nearly always given by social inferiors to their superiors, and the most usual donors of illuminated books were courtiers seeking favor or employment. Following this line of reasoning, the donor (or donors) of Arundel 66 is likely to have been close to the royal household. The difficulty is that a book on the scale of Arundel 66 was almost certainly beyond the means of any one of the scholars who clustered around the king in the hope of preferment.

The provenance and decoration of the manuscript provide additional clues about the donor as well as its cultural context. Arundel 66 was an English book: both its text and its illustrations were executed by artists and scribes living in England, probably in London. Scott suggests that the lengthy text was completed by a single scribe and was then lavishly embellished

\footnotetext{
${ }^{39}$ Yale University, Beinecke Rare Book and Manuscript Library, MS Mellon 25; Yale Online Catalogue.

${ }^{40}$ For Engel, the finest scientific editor of his age, see Dobrzycki and Kremer. This article includes an example of Engel's handwriting that is clearly not the same as that of "John Wellys" in Arundel 66.

${ }^{41}$ Buettner, 604 .

${ }^{42}$ Alexander, 141-62.
} 
by three artists with a comprehensive program of illumination. ${ }^{43}$ All its decorative elements were executed in the Burgundian, or Flemish, style made popular in England through the patronage of the Valois Dukes of Burgundy and their Lancastrian allies. ${ }^{44}$ The same style was deployed for the imposing illuminated secular manuscripts in French on didactic subjects that Edward IV ordered for the Royal Library between 1478 and $1480,{ }^{45}$ and for London, BL, Royal 20 E I (Chroniques de France), which was commissioned by Thomas Thwaytes (d. 1495) for Henry VII. ${ }^{46}$ Apart from the exceptional initial on fol. $201^{\mathrm{r}}$, the decorative elements of Arundel 66 are not of the highest artistic quality, but, like those intended by Thwaytes for the Chroniques de France, they are extensive. There is ornament of some kind on almost every page, including forty-three miniatures and twenty-five historiated initials, a number of which incorporate full or partial foliated borders (fols. $53^{\mathrm{r}}, 201^{\mathrm{r}}$ ). Given its considerable weight — almost too heavy to lift — it can probably be assumed that whoever commissioned Arundel 66 intended it to be read from a stand or lectern. It was certainly designed to impress.

The miniatures all appear in the second major item in the manuscript, where they illumine the catalogue of forty-five constellations (see fig. 5). ${ }^{47}$ Each of the ten books of Guido Bonatti's Introduction to astrology begins with a showy historiated initial. ${ }^{48}$ While the first, on the utility of astrology (fol. $53^{r}$ ), is relatively plain, the second, on the signs $\left(\right.$ fol. $57^{r}$ ), has a fine golden dragon from whose curling tail another dragon emerges breathing golden fire. The third book, on the planets, has a blazing sun illuminated in gold (fol. $80^{\mathrm{v}}$ ). A golden crown adorns the letter $C$ beginning the fourth, on conjunctions (fol. $86^{\mathrm{r}}$ ). Besides the initial for the eighth book (fol. $201^{\mathrm{r}}$ ), the most striking of these initials begins book seven, on elections (fol. 129 ${ }^{r}$ ). Because elections were used to choose dates for weddings, coronations, and other important occasions, this may have been a part of the manuscript where a court astrologer might

\footnotetext{
${ }^{43}$ Scott, 1996, 364-67.

${ }^{44}$ Kren and McKendrick.

${ }^{45}$ Stratford and Webber, 1:214.

${ }^{46}$ London, British Library, MS Royal 20 E I-E VI, also called Chroniques de France (hereafter BL MS Royal 20 E I-E VI).

${ }^{47}$ For astrological iconography in Northern and Southern Europe, as well as painting, sculpture, and manuscript illumination, see Blume in addition to sources listed in $\mathrm{n} 1$ above.

${ }^{48}$ As indicated in the index (fols. $48^{\mathrm{r}}-52^{\mathrm{v}}$ ), the ten books are: 1 . On the utility of astrology; 2. On the division of the signs and their effects; 3 . On the nature of the seven planets; 4. On conjunctions; 5. On considerations pertaining to judgements; 6 . Judicial questions with three introductory chapters; 7 . Elections; 8 . Revolutions of the years on the world; 9. On nativities and their accidents; 10 . On rain and the changing of air.
} 


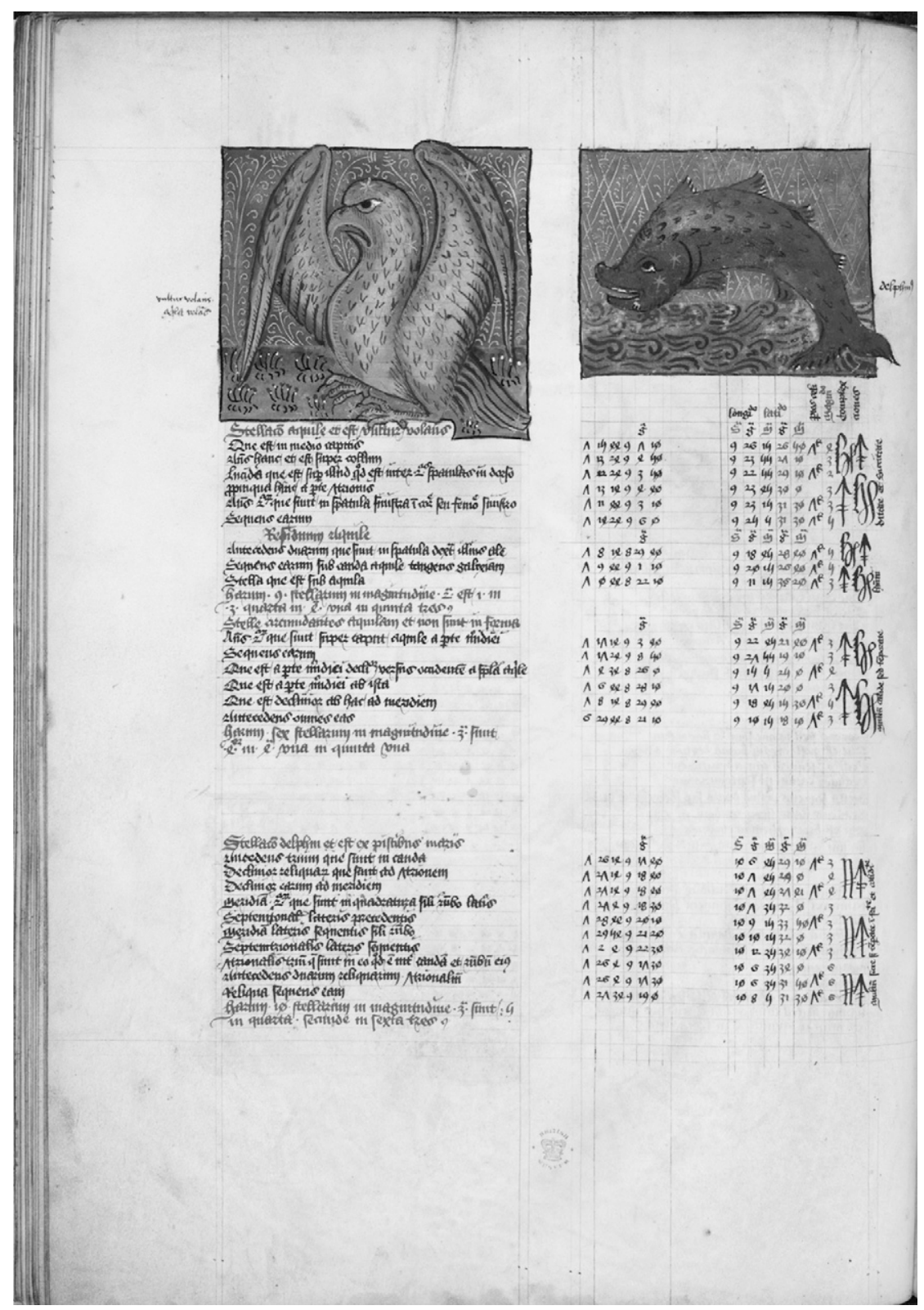

FIGURE 5. Constellations Aquila and Delphinus. MS Arundel 66, fol. 37\% Courtesy of the British Library Board. 
hope to regularly draw the attention of a royal client. ${ }^{49}$ This initial has a golden dragon whose body is split in two; its tongue impales a tree surmounted by an imperial crown studded with jewels. ${ }^{50}$ A more domestic scene fills the historiated initial (fol. 148 ${ }^{\mathrm{r}}$ ) that begins book 9, on nativities (fig. 6). This shows a woman lying in a childbirth bed who reaches out to a baby held by a nurse while a star radiates into the bed chamber.

In addition to these purely decorative elements, the manuscript contains many clear scientific diagrams and tables. These are a spectacular feature of the Canons and Tables of John Killingworth (fols. $1^{\mathrm{v}}-32^{\mathrm{r}}$ ), where many lines are lavishly ruled in gold, but there are fine diagrams throughout the manuscript. On fol. $92^{\mathrm{v}}$ there are horoscopes for questions concerning a wedding (questio de coniugio) and power (questio de potestate); another worked example of a horoscope, dated to 1265 , appears on fol. $184^{\mathrm{r}}$. There is a circular diagram displaying the different aspects of the planets conjunction, opposition, trine, and quartile - on fol. $158^{\mathrm{v}}$ and another that summarizes the qualities - earth, air, fire, and water — in relation to the twelve houses on fol. $286^{\mathrm{r}}$. Although some diagrams are missing - for example, the horoscope on fol. $232^{\mathrm{r}}$, and some elements of the Alfonsine Tables (fols. $250^{\mathrm{r}}-266^{\mathrm{r}}$ ) - the scientific data is executed with accuracy and clarity. There are also many circular diagrams in the book of geomancy by Alpharinus.

The manuscript also has a range of heraldic ornament that stresses its royal Tudor credentials, including the imperial bush on fol. $129^{\mathrm{r}}$, red and white roses (fols. $1^{\mathrm{v}}, 179^{\mathrm{v}}, 187^{\mathrm{r}}, 201^{\mathrm{r}}, 243^{\mathrm{r}}$ ), crowns (fols. $86^{\mathrm{r}}, 129^{\mathrm{r}}$ ), and dragons (fols. $29^{\mathrm{r}}, 57^{\mathrm{r}}, 97^{\mathrm{v}}$ ), together with a colorful riot of flowers and birds. Nevertheless, compared with other royal manuscripts, Arundel 66 lacks a number of important Tudor emblems and supporters, including the portcullis, griffin, red (as opposed to gold) dragon, and, above all, the union rose, said to represent the marriage of the Lancastrian Henry Tudor to the Yorkist Elizabeth, daughter of Edward IV, on 18 January $1486 .^{51}$ But enough remains to make the alternative hypothesis - that the manuscript was commissioned for someone other than a member of the Tudor royal family in the 1490 s — seem rather unlikely.

${ }^{49}$ For medieval client-based judicial astrology, including elections and interrogations, see Carey, 2010b. For earlier accounts of English medieval and Renaissance astrology, see Curry; Eade; North, 1986.

${ }^{50}$ The imperial crown on a bush is another Tudor badge that refers to the retrieval of the crown from under a hawthorn bush following the death of Richard III at the Battle of Bosworth.

${ }^{51}$ Anglo, 1992, 34. 


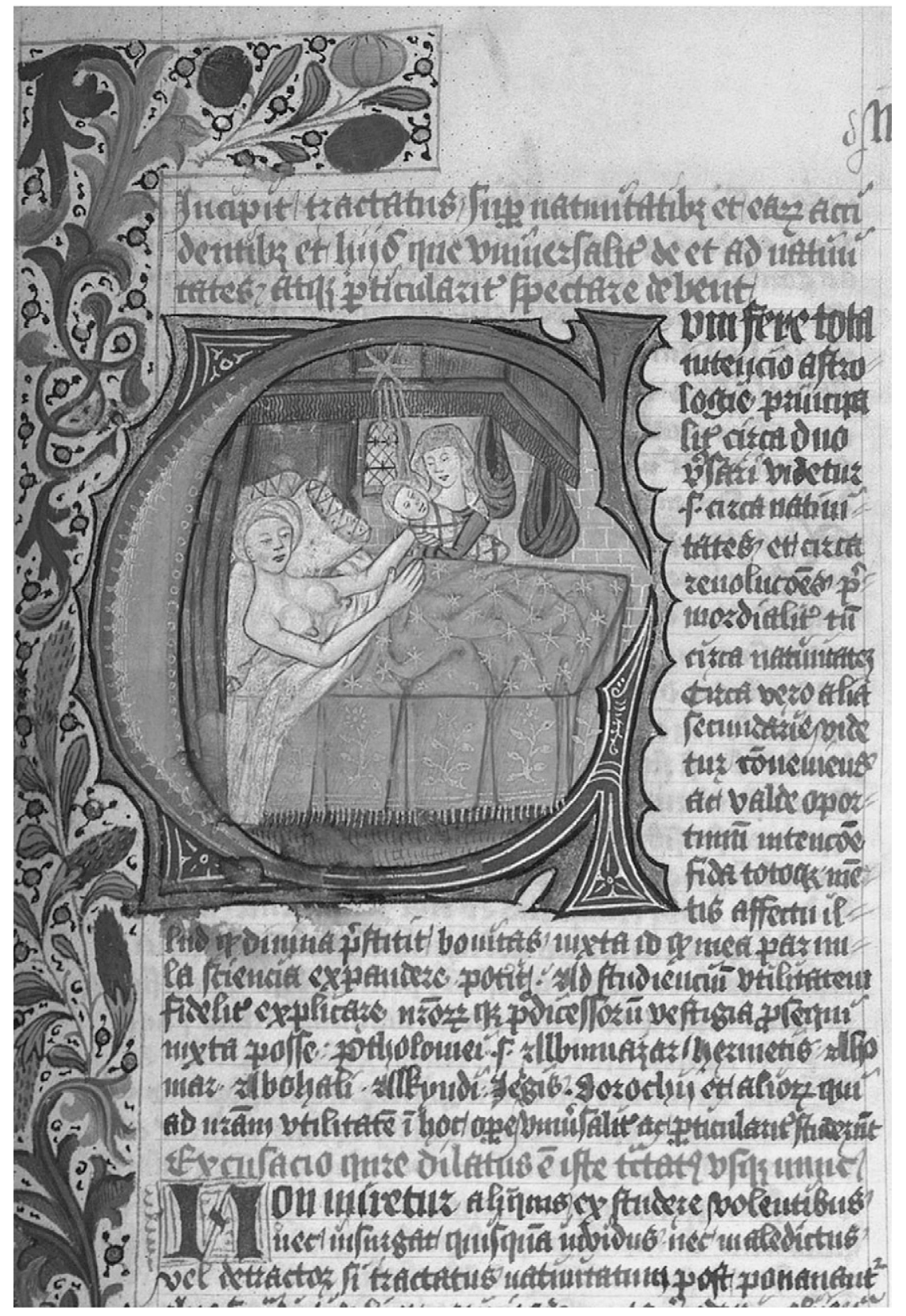

FIGURE 6. Historiated initial opening Guido Bonatti's Introduction to astrology, bk. 9 on nativities. MS Arundel 66, fol. $40^{\mathrm{r}}$. Courtesy of the British Library Board. 
The most important evidence for determining the patronage context of the manuscript is the historiated initial with full border on fol. $201^{\mathrm{r}}$ (see figs. 1 and 2). According to McKendrick, the miniature was executed by the Flemish artist of the Master of 1482 who also worked on the Chroniques de France. ${ }^{52}$ It is the finest illumination in the manuscript. At the simplest level, it depicts an English king being presented with a book. The king sits enthroned under a canopy that has the royal arms of France and England quartered. He wears the newly favored imperial crown, ${ }^{53}$ and carries a scepter in his left hand. He is robed magnificently in gold silk that is decorated with roses within and with artichokes and pomegranates, the emblem of Katherine of Aragon, on the outer mantle. ${ }^{54}$ Nevertheless, although this has long been assumed, this image is clearly not a donor portrait: for one thing, it is not placed at the beginning of the book; for another, it lacks a colophon explaining the circumstances of the gift, as, for example, in Quentin Poulet's presentation copy of the Imaginacion de vraye noblesse for Henry VII (fig. 7). ${ }^{55}$ Instead, the miniature illustrates the opening of Bonatti's eighth chapter, which concerns the branch of astrology known as "revolutions of the year," or annual prophecies based on the state of the heavens at the time of the sun's entry into the first degree of Aries. William Parron prepared predictions of this type, some of which he dedicated to the king, from about 1496 to 1502 . According to the artist or rather the patron who directed the design of the miniature - a large number of people were present for the occasion. Representing secular authority, there are twelve figures on the king's right, as well as two dogs, one of which appears to be a Beaufort greyhound. One martial figure, wearing a Lancastrian SS livery collar and a Tudor rose pendant, ${ }^{56}$ holds a sword of state. ${ }^{57}$ The clothes and hats of a number of other armed retainers bear royal badges. On the king's left there are four figures, including an

\footnotetext{
${ }^{52}$ The Online BL Catalogue has: “ex info. Scott McKendrick.” See McKendrick, pl. 91, for a reproduction of this miniature.

${ }^{53}$ Hoak.

${ }^{54}$ The pomegranate is a common motif on fifteenth-century textiles, so there is no necessary reference to Katherine of Aragon, though for the latter, see Johnston.

${ }^{55}$ London, British Library, MS Royal 19 C VIII (hereafter BL MS Royal 19 C VIII).

${ }^{56}$ Fletcher.

${ }^{57} \mathrm{~A}$ sword of state of comparable size and design, dated ca. 1460-70, and bearing the heraldic devices of a Prince of Wales, is now in the British Museum. See Marks and Williamson, 179.
} 


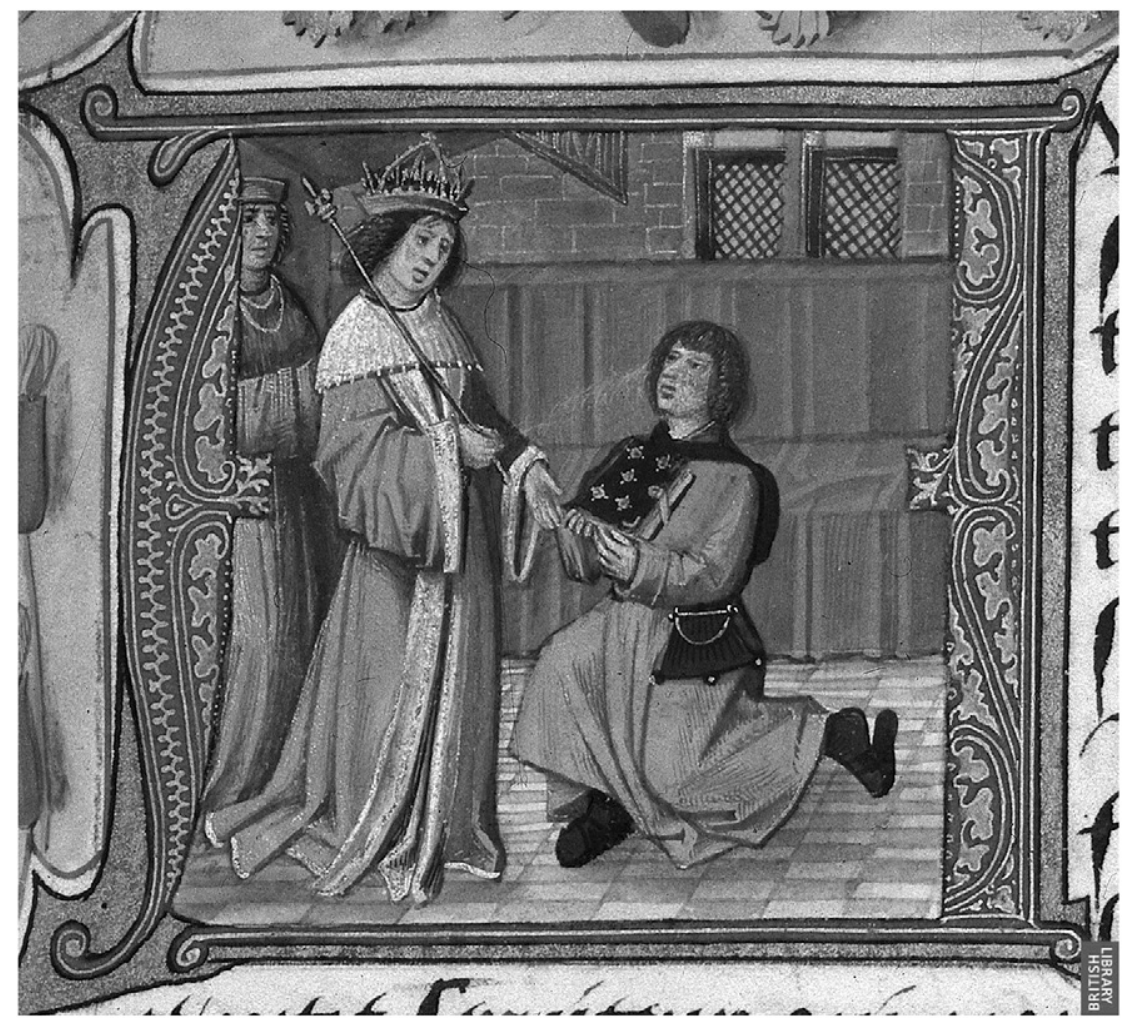

FIGURE 7. Quentin Poulet and Henry VII, Royal 19 C VIII (Imaginacion de vraye noblesse), fol. 1. Courtesy of the British Library Board.

archbishop who lends his sanction to the event by pointing to the stars. ${ }^{58}$ Two kneeling figures — one of which also points to the stars - make the actual presentation while a third hovers in the background.

Can any of these courtiers be identified? Fortunately, the foremost kneeling figure, who is richly dressed with a blue coat trimmed with fur, ${ }^{59}$ is carefully labeled. With one hand he supports the presentation of the book to the king; the other holds a shield bearing the arms of the Valois Dukes of

${ }^{58}$ Parron provides an extended defence of astrology from ecclesiastical censure of various kinds. The presentation copy is Oxford, Bodleian Library, MS Seldon Supra 77, also called Libellus de astrorum succincte vi fatali (hereafter Bodleian MS Selden Supra 77). For the theological standing of astrology, see Smoller; Veenstra; Wedel.

${ }^{59}$ Possibly the heraldic erminois, i.e., or with sable spots, but in any case a spotted fur that is a darker version of the ermine of the king's robes. 
Orleans. ${ }^{60}$ In the 1490 s there was only one man entitled to bear these arms, namely, Louis II, Duke of Orleans, who assumed the title upon the death of his father, Charles of Orleans, in 1465. He would go on to reign as King Louis XII of France and, in 1514, marry Henry VII's daughter, Mary Tudor. ${ }^{61}$ He was, in other words, a key strategic ally of the Tudor dynasty and one of the most powerful men in Europe. From 1489 to 1491, Henry VII and Duke Louis were joined in the ducal coalition that fought to prevent the incorporation of Brittany into the French royal domains. Although some historians see the Breton wars as a diversion from the English king's main business - which in their view should have been the consolidation of his rule at home - Currin has argued that they were not a sideshow. ${ }^{62}$ Nevertheless, despite their close diplomatic and military ties, Duke Louis had little opportunity to arrange presents for the English king. In alliance with Francis II, Duke of Brittany - the ally and protector of the Lancastrian exile Henry Tudor before his accession - he was still entangled in the Mad War (La Guerre folle) against the young Charles VIII of France. He was captured at the Battle of Saint-Aubin-du-Cormier on 28 July 1488, and until 1491 was confined for his role in the rebellion. ${ }^{63}$ This makes it unlikely that he was personally involved in the commission of Arundel 66 even if the manuscript can be dated to sometime after his release and eventual accession in 1498 as King of France. His depiction in this image is probably meant to suggest that Duke Louis endorsed King Henry's reception of astrological advice for the good of his realm.

An alternative theory suggests that the miniature illustrates the reception of a French ambassador at the court of Henry VII. ${ }^{64}$ Apart from the fact that the coat of arms is not that of France but carries the heraldic label of the Duke of Orleans, this has to be discounted on other grounds. It is true that in 1489 a French ambassador, the cleric and humanist Robert Gaguin (1433-1501), came to the court of Henry VII in order to seek support for

${ }^{60}$ Fox-Davies, 486. The arms were borne by Charles of Orleans, captive in England after the Battle of Agincourt from ca. 1405-20. They appear, for example, on Paris Bibliothèque nationale, MS latin 1196, also called The Prayerbook of Charles d'Orléans, illustrated by Herman Scheerre.

${ }^{61}$ The account that follows relies on Baumgartner, 27-38. For comparison, the illustration in Arundel 66 is not unlike the image of Louis II painted by the portraitist Jean Perréal in 1500.

${ }^{62}$ For Henry VII's involvement in the Brittany affair, see Currin, 1999, 2000, and 2002. For other accounts of Henry VII during this period, see Alexander, 89-96; Bevan; Chrimes, 1966; Chrimes, 1972, 280-82.

${ }^{63}$ Baumgartner, 34-35.

${ }^{64}$ Royal Manuscripts, no. 99. 
Charles VIII's claim to Naples and to recognize the dissolution of the marriage between Anne, Duchess of Brittany, and the Holy Roman Emperor. ${ }^{65}$ However, the mission was a spectacular failure. Henry was openly hostile to the French claims and his humanist courtiers responded, presumably with the king's encouragement, with an elaborate flyting, or invective, in Latin verse. One of the milder verses, composed by the Italian Giovanni Giglis, stated: "Why is no one able to trust you, Frenchman, so often are lies thus put forth by you? We believe that your intention was to undo holy peace, since no ancestor of the French has loved us." ${ }^{\text {"66 }}$ Having secured the maximum possible propaganda to humiliate French pretensions, Henry proceeded to invade France in $1492 .{ }^{67}$ It strains belief that such an inauspicious occasion would be selected for depiction in a royal manuscript intended to secure the king's favor. In addition, the figure in the miniature is clearly an untonsured layman, whereas Gaguin, general of the order of the Maturins, was a cleric.

As has already been suggested, a more convincing reading of the miniature is that it represents a window onto the court at the time the king's astrologer presented him with astrological predictions for the coming year. If we accept this thesis, there are, besides the king and the Duke of Orleans, several individuals who may be identified, albeit tentatively, on the basis of their regalia. ${ }^{68}$ In the 1490 s, the Archbishop of Canterbury (with the cross and miter) was Cardinal John Morton (r. 1486-1500) and the Chancellor of the Exchequer (with the sword of state) was the soldier Sir Thomas Lovell (r. 1485-1524). Of the lesser courtiers, William Parron would be the astrologer making the presentation: he wears a hood that is folded around his neck like that of a scholar. While Duke Louis dominates the foreground, it is actually Parron who holds the book while the duke supports the offering with one hand. Behind Parron there is another kneeling figure who wears a distinctive brimless high-crowned cap. This may be intended as one of the king's Italian humanist secretaries, such as Giovanni Giglis or Filippo Alberici. ${ }^{69}$ While these identifications help to flesh out the intended audience of Arundel 66, they unfortunately bring us no closer to identifying either the donor or the designer of the manuscript.

Heraldry can sometimes provide a more specific answer to the question of who was responsible for the commission of a book as elaborate as

${ }^{65}$ Edwards.

${ }^{66}$ Analysis and translation by Carlson, 1988, 298.

${ }^{67}$ Ibid.

${ }^{68}$ Following Royal Manuscripts, no. 99.

${ }^{69}$ For Alberici, see Rundle, 2005. The composition of Henry VII's court is discussed by Gunn, 1993. 
Arundel 66. Heraldry was integral to the grammar of Renaissance kingship and patronage: books and other objects intended for royal attention were constantly reworked in line with royal favor, marriages, births, and deaths. It was essential to the careful fashioning of the image of the Tudor kings and helped create the atmosphere of princely magnificence that was understood to be essential to effective government. ${ }^{70}$ If anything, books presented to the king were even more likely to be embellished with his and his family's royal arms and the emblems than those that were part of his personal library.

There are two royal manuscripts that can demonstrate this point. Both were made for presentation to Henry VII and, like Arundel 66, they therefore say less about his personal taste than what his courtiers thought would invite his favor. BL Royal 19 C VIII is a fine illuminated copy of the Imaginacion de vraye noblesse, which was executed and/or commissioned for presentation to the king by his librarian, Quentin Poulet, the scribe and illuminator who was keeper of the Royal Library from 1492 to 1506 (fig. 7). Based on the colophon on fol. $97^{\mathrm{v}}$, this manuscript was completed in 1496 at Sheen. It includes six fine miniatures, including a historiated initial with Poulet's donor portrait, and other indications of its royal provenance, including the royal arms of England and red Lancastrian roses scattered among other marginal flowers, birds, and animals. ${ }^{71}$ The folio containing the donor portrait has this ingratiating dedication by Poulet: "To you, my most formidable sovereign lord, the most high, the most excellent, the most powerful and most victorious prince, Henry, the seventh of that name, King of England and of France."72 In the donor portrait Poulet is shown kneeling alone, wearing the royal livery, to present his book to the king, who is depicted standing to receive it.

Another manuscript whose style and execution can be compared with Arundel 66 is BL MS Royal 20 E I-VI. ${ }^{73}$ Now in six parts, this is a sumptuous copy of the French Chroniques de France, with the continuation to 1461 , that was prepared for donation to Henry VII by Thomas Thwaytes (d. 1495), treasurer of Calais, by his "poor clerk and humble servant" Hugues de Lembourg. ${ }^{74}$ This is explained in the colophon of Royal 20 E III,

${ }^{70}$ Anglo, 1992, 6.

${ }^{71}$ BL MS Royal 19 C VIII, fol. $3^{\mathrm{r}}$.

${ }^{72}$ Ibid., fol. $1^{\mathrm{r}}$ : "A vous mon tres redoubte souverain seigneur le tres hault tres excellent tres puissant et tres victorieux prince Henry septiesme de ce nom Roy dangleterre et de france."

${ }^{73}$ Warner and Gilson, 387-88.

${ }^{74}$ Backhouse, 1987 and 2000 argue that Lembourg is also responsible for the original work on the poems of Charles of Orleans (London, British Library, MS Royal 16 F II) in the late 1480s. 
fol. $94^{\mathrm{v}} .^{75}$ The manuscript might also hint at the kind of reward Thwaytes would appreciate for his efforts. The full-page miniature and border on fol. $3^{\mathrm{v}}$, where it is almost the first thing in the book, shows barons electing a king while three bishops undertake the coronation in another room. The border has the usual wealth of Tudor emblems that is lacking in Arundel 66 - portcullises, red and white roses, and other flowers and fruit such as columbines, violets, and strawberries - but it also shows a less-usual focus on the Order of the Garter. The border has three coats of arms: of England, Edward the Confessor, and St George surrounded by a garter with the royal motto "Dieu et mon droit." Possibly there is an association with the occasion of the making of a knight of the garter whose ranks the donor aspired to join. ${ }^{76}$

Unlike Arundel 66, the Chroniques de France is lavishly embellished with all the arms, badges, emblems, and mottos of Henry VII, which include floral borders with red and white roses, red and white roses surmounted by a crown, ${ }^{77}$ portcullises, a royal coat of arms, supporters of red wyvern, white greyhound, white hart, red lion, and scrolls. Less conspicuous are the arms of the donor, namely, a shield argent on a fess sable three bezants. ${ }^{78}$ In both cases where it appears, the Thwaytes coat of arms is low-key and small in scale. It appears in borders together with numerous other Tudor badges, including on fol. $155^{\mathrm{v}}$, a large Tudor rose in striking red and white, with portcullises and a wyvern, holding a green and white standard, atop the royal crown. If the donation of the Chroniques formed part of a campaign by Thwaytes to ingratiate himself with Henry VII, it was unsuccessful. In 1494 he was arrested for treason, and he never became a knight of the garter. Both of these examples, Royal 20 E I-E VI (Chroniques de France) and Royal 19 C VIII (Imaginacion de vraye noblesse), were presented to the king by courtiers, or by those who hoped to seek his favor or patronage. They are a good indication of how expensive it could be to try and stay within the royal circle, and the sort of investment that had to be made to secure a position.

Arundel 66 would appear to lack both the donor portrait and colophon, or the specific heraldic embellishment that would allow

${ }^{75}$ Cited in Warner and Gilson, 387.

${ }^{76}$ I thank Professor Linne Mooney for this suggestion. In 1488, three men were made knights: George Talbot, Fourth Earl of Shrewsbury; Sir Edward Wydville, afterwards Lord Wydville; John, First Viscount Welles, Captain in the forces of the Earl of Richmond, Henry VII. Welles was Henry VII's uncle.

${ }^{77}$ BL MS Royal 20 E III, fol. $155^{\mathrm{v}}$.

${ }^{78}$ Ibid., fol. $152^{\mathrm{v}}$, fol. $155^{\mathrm{v}}$. For analysis of the Thwaytes blazon, see http://www.apl385. com/gilling/blazon.htm. 
a direct identification of the donor. However, there may be a subtle invocation of the family arms of Richard Fitzjames in two places in the manuscript. Fitzjames was a chaplain to Edward IV, Warden of Merton College, Oxford from 1483 to 1507 , almoner to Henry VII (1495), and, successively, Bishop of Rochester (1497), Chichester (1504), and London (1506). ${ }^{79}$ Beginning in the 1490 s, he made innumerable heraldic displays of both his Fitzjames and Draycot family arms, including the charges of the dolphin embowed (Fitzjames) and eagle displayed (Draycot), throughout the buildings, books, and furnishings that he endowed in the course of his distinguished career in royal, academic, and ecclesiastical service. ${ }^{80}$ The constellations of Aquila (Eagle) and Delphinus (Dolphin) are close together in the Northern sky and it is not significant that they appear together in illustrations of the constellations. The captions to those in Arundel 66 (fol. $37^{\mathrm{v}}$ ) specify that "the constellation Aquila is a bird of prey flying," while Delphinus is "from the fish of the sea." 81 Tabular depictions of the constellations and Renaissance maps such as Albrecht Dürer's printed Maps of the Northern and Southern Sky (1515) follow these descriptions and show Aquila dramatically swooping through the air while Delphinus balances acrobatically on its tail. ${ }^{82}$ Non-tabular constellations follow a different tradition. ${ }^{83}$ The constellations in Arundel 66, however, are rather distinctive: Aquila does not swoop but is depicted as the heraldic eagle displayed, that is, standing on the ground with wings outstretched,

${ }^{79}$ The multiple sees maximized income for the king, who gained financially from the translation of prelates in his domains.

${ }^{80}$ Bott, 197-203 (Appendix II). Fitzjames displayed his arms with many variations, and sometimes with eagle and dolphin together. For example, as Bishop of London (after 1506), Azure a dolphin embowed argent, quartering argent a cross engraved sabine in dexter chief an eagle displayed gules. See Papworth, 836.

81 "stellacio aquile et est vultur volans"; "ex piscibus maris." See fig. 3.

${ }^{82}$ Tabular depictions of the constellations generally derive from Al-Sufi's Book of the Fixed Stars 1009-10 (AH 400) and, as in Arundel 66, include astronomical data and images. Lippincott, 1985, 70 identifies the star catalogue in Arundel 66 as "miscellaneous," because although it is tabular in format the illustrations derive from non-tabular traditions. For Aquila and Delphinus in the Camera di Griseldi vault, see Lippincott, 1985, Plate 14b. For color reproductions of fifteenth- and sixteenth-century constellation and horoscope maps, including those by Dürer and the Camera di Griseldi, see Zuffi and Navellone, 36-37, 39.

${ }^{83}$ For non-tabular, though also non-heraldic, depictions of Aquila and Delphinus, see Oxford, Bodleian Library, MS Bodley 614, fols. 29 $9^{\mathrm{r}}, 29^{\mathrm{v}}$ (English, mid-twelfth century), and Oxford, Bodleian Library, MS Laud Misc. 644, fol. 10 (French, ca. 1268-74). For a fifteenth-century Spanish Tapestry of the Constellations in the Museo de Santa Cruz, Toledo, with a swooping Aquila and embowed Delphinus, baring teeth, see Zuffi and Novellone, 33. 
while Delphinus is shown as the heraldic dolphin embowed, that is, arched and leaping though the waves and baring its teeth. In 1497 Fitzjames made a similar substitution of the heraldic dolphin embowed for the usual depiction of the constellation Pisces in the zodiac arch he erected at Merton College, Oxford. A second allusion to Fitzjames may be reflected in the heraldic eagle displayed that stands amid the red and white roses adorning the margin of the opening folio of Guido Bonatti's Book of astrology (see fig. 3). The eagle bears the motto "Vyve le roy," a very fitting sentiment for a king's man such as Fitzjames.

To summarize the argument so far: it is reasonable to assume that Arundel 66 was commissioned in the 1490s as a gift for Henry VII, even though it does not fit the conventional view of his taste and interests. The contents of the manuscript suggest that it was intended to demonstrate English achievement in the science of the stars and in other forms of prophecy, and to enhance the prestige of the Tudor dynasty. The identity of the donor remains elusive, though the manuscript appears to contain heraldic allusions to Richard Fitzjames, one of Henry VII's closest courtiers and an ardent and wealthy enthusiast for astrology. The miniature on fol. $121^{\mathrm{r}}$ provides vital evidence for the reception of astrology at the court of Henry VII in the 1490s. It depicts the king being presented with annual predictions by his astrologer, William Parron, with the support of representatives of both church and state.

The next section will look beyond the manuscript to three Tudor courtiers who demonstrated a particular fascination with astrology in the 1490s. This is not to argue that they were necessarily responsible for the commission of Arundel 66, but rather because they are likely to have made up the kind of admiring audience for the king's patronage of astrology that is invoked by the illustration on fol. $121^{r}$. First and foremost there is the king's own astrologer, William Parron. Second is Richard Fitzjames, who has already been discussed in relation to the heraldic evidence of the donor of the manuscript. Third is Lewis Caerleon, a physician and collector of astronomical and astrological manuscripts who served both Henry's consort, Elizabeth of York, and the king himself. No doubt there were other astrological enthusiasts at Henry's court: these three are the ones about whom we have the most historical evidence.

\section{Three Tudor Astrologer Courtiers}

Parron is generally referred to as Henry VII's astrologer, although the king extended only limited direct patronage to him, and even this seems to have dried up after 1503. As usual, there is more evidence of Parron's efforts to 
secure the king's favor than of the king's response to him. ${ }^{84}$ In his printed and manuscript works Parron claims to be a physician, doctor of medicine, professor of astrology, and doctor of arts: while there is no surviving evidence for any of these qualifications, he may have studied at Pavia, the new studium of the Duchy of Milan. ${ }^{85}$ On his own account, he came to England in the 1480 s and made a number of successful predictions. In the 1490s he worked hard to secure court patronage from the incoming Tudor regime and dedicated a series of works to Henry VII. A presentation copy of a libellus (little book) - probably the first work he prepared for the king, De astrorum succincte vi fatali (Concerning the Deadly Power of the Encircling Stars), completed on 15 October 1499 - is now in the Bodleian Library, Oxford. ${ }^{86}$ Its purpose was to convince the king of his need to seek professional help against the devastating power of the stars, such as the malign fates that ordained the destruction of the sons of Edward IV, ${ }^{87}$ and also to defend astrology on rational and theological grounds against its detractors. A historiated initial on the opening folio makes the same point by depicting a king supported by tonsured clerics on one hand and lay courtiers on the other. After the untimely death of Prince Arthur, Parron prepared a treatise, the Liber de optimo fato, concerning the excellent fortune of Henry, Duke of York - the future Henry VIII — and his two illustrious parents, in two presentation copies that were decorated in the Burgundian style. ${ }^{88}$ This manuscript also depicts the king enthroned at court. Although the work is inferior to that of Arundel 66, the color and iconography of some elements is similar and could reflect copying, something likely enough if Parron had access, possibly through Quentin Poulet, to books in the Royal Library. It is interesting, for example, to compare the figure of the elegant turbaned woman and child in Arundel 66, fol. $148^{\mathrm{r}}$, where it marks the beginning of Guido Bonatti's treatment of nativities in book nine, with the miniature that opens Parron's Liber de optimo fato on the nativity of Prince Henry (see figs. 6 and 8$)$.

${ }^{84}$ Armstrong; Carlin.

${ }^{85}$ Azzollini, 190. For the titles, which all come from his own writings, see Carlin.

${ }^{86}$ Bodleian MS Selden Supra 77.

${ }^{87}$ Ibid., fol. $18^{\mathrm{r}}$.

${ }^{88}$ London, British Library, MS Royal 12 B VI (hereafter BL MS Royal 12 B VI): Liber de optimo fato nobilissimi domini Henrici Eboraci ducis et optimorum ipsius parentum (Book Concerning the Excellent Destiny of the Lord Henry Duke of York and the Most Excellent Destinies of his Parents). Paris, Bibliothèque nationale, MS latin 6276 is another presentation copy of the same text. 


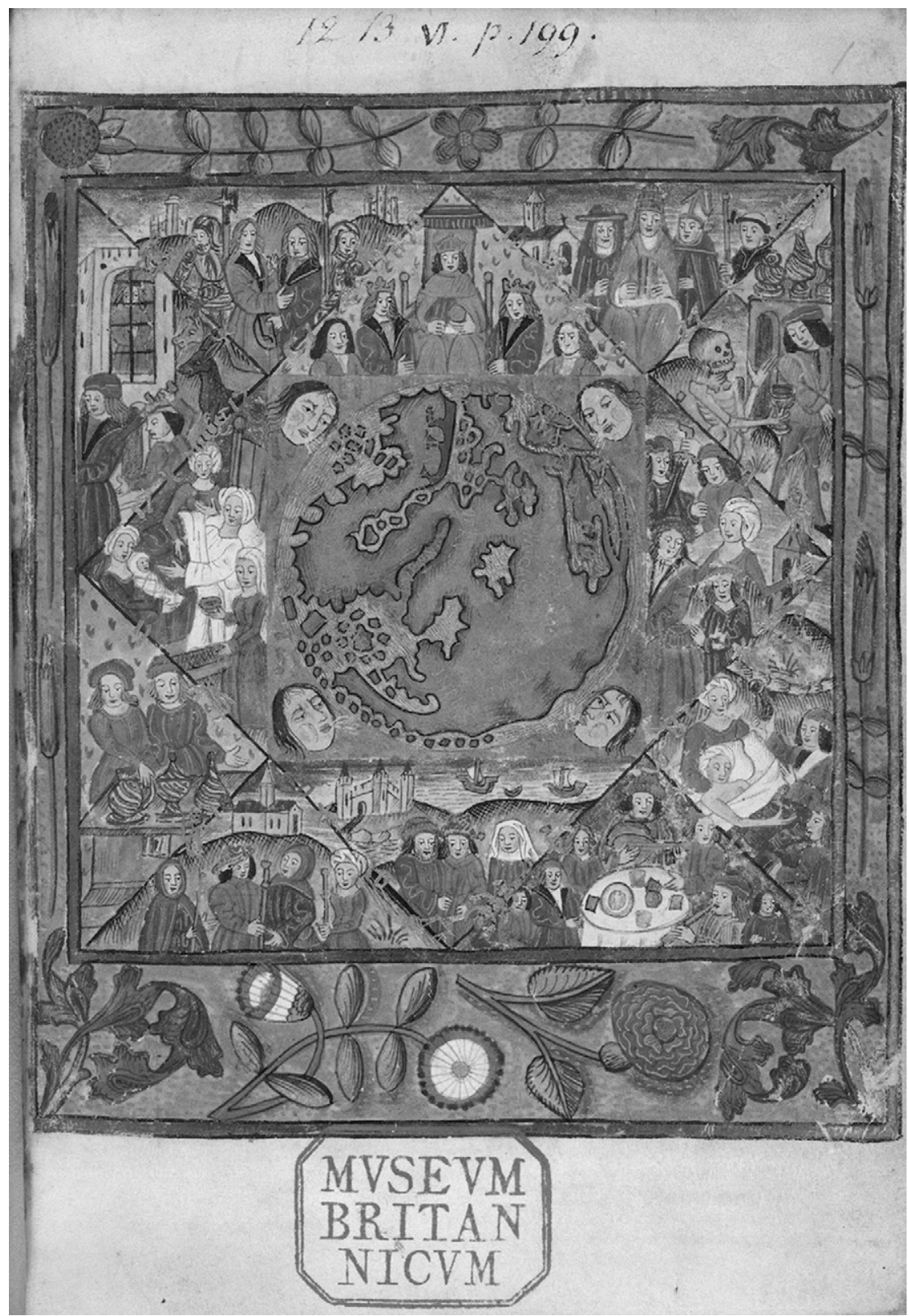

FIGURE 8. Illustrated horoscope from Parron, Liber de optimo fato nobilissimi domini Henrici Eboraci ducis, 1502. BL Royal MS 12 B VI. Courtesy of the British Library Board. 
Parron can be seen as something of a forerunner of the Italian astrologer physicians who received academic training and who sought court patronage for their expertise in Northern courts from the late fifteenth century. Like many of them, his remuneration from this source was precarious and he also took advantage of the new market in annual prognostications, which were undergoing the transition from manuscript to print. ${ }^{89}$ From 1496 to 1503 he prepared a series of general predictions for a wider audience, a number of which were dedicated to Henry VII. ${ }^{90}$ Whitfield argues that Parron was disgraced and banished from the court due to the inaccuracy of his forecast that failed to predict the death of Prince Arthur, on whom so many hopes had been pinned; ${ }^{11}$ however, this is unwarranted speculation. In both his surviving prognostications, Parron's comments on Arthur were perfectly innocuous, simply stating that Parron could foresee no particular problems arising for him. The 1502 comments amount to no more than a few words: "The illustrious Arthur, Prince of Wales will be safe [and] triumphant."92 While this was clearly wrong, Parron also provided solid positive reinforcement to the fortunes of the king's allies, including King Louis of France and King Ferdinand of Aragon; and, in 1500, he mentioned the outstanding prospects for the negotiations for a marriage with the latter. ${ }^{93}$ He was less cautious in the predictions that he made for the length of life of the king and his consort, which predictions he says he made on the basis of the birth charts of the king, his queen, and the young Henry, Duke of York, as well as on the king's coronation. All the astrological indicators, he argued, were conjoined in suggesting that the king would live for a hundred years, while Elizabeth of York could expect eighty or even ninety years of life. ${ }^{94}$ Unfortunately the queen died within months of this prediction on 11 February 1503 . While this was unlucky, Parron had taken pains to explain to the king that prediction of length of life for individuals was a difficult matter that was at all times subject to the grander astrological forces that brought epidemics, corruption

${ }^{89}$ Capp, 26.

${ }^{90}$ Two of Parron's Latin Prognostications survive, both by Pynson: a complete copy of that for 1500 (printed 24 December 1499) and fragments for 1502. There is also a fragment of an English translation, ca. 1498, printed by W. de Worde. See Bosanquet, 20, 79-80, pls. V-VI; Capp, 19, 26, 67, 68, 112. The earliest English prognostication, printed by Caxton in 1493, was a translation of an almanac by the Laet family of Antwerp.

${ }^{91}$ Whitfield, 2001, 142-44.

${ }^{92}$ Parron, 1501, fol. Bii. Illustrissimus arthurus princeps Walie etc. erit icolumis triumphans.

${ }^{93}$ Parron, 1499, fol. bii.

${ }^{94}$ BL MS Royal 12 B VI, fol. $31^{\text {v }}-32$. 
of the air, or wars, which was the reason astrologers sometimes appeared to err. ${ }^{95}$ No reputable astrologer would claim to be infallible.

As to his connection with Arundel 66, Parron had the relevant expertise to have contributed intellectually to its compilation, and he presented two smaller works of astrology decorated in a similar style to the king; he also appears to be depicted in the manuscript at fol. $66^{\mathrm{r}}$. Nevertheless, he was not a wealthy man and it is apparent that Arundel 66 was executed on a scale that was beyond both his ambition and his capital. There is one payment of $£ 1$ to "Master William Paronus, an astronymyre" in the privy purse accounts for 6 March 1499, and this may relate to the execution of the Libellus de astrorum succincte vi fatali earlier in the year. ${ }^{96}$ This is a very modest stipend for a courtier in attendance at the court of Henry VII. ${ }^{97}$

Despite his small income, we should not assume that Parron lacked influence either at court or with the broader audience of educated clerics and laypeople beyond it. In his own writings Parron represents himself as a scholar, physician, and "professor of astrology." With his Italian education and learning, he shared the intellectual prestige and glamour that had earned a place at the Tudor court for other French and Italian humanists. As Rundle has argued in relation to other humanist works composed for Henry VII by his court intellectuals, one should no longer follow the lead of the distinguished Renaissance scholar Richard Weiss and assume that the corpus of Latin writing these clerks produced was either incomprehensible to Henry, or that they failed to address his particular interests and political concerns. ${ }^{99}$ Indeed, it can be argued that the king would not have approved payment to Parron, nor would he have accepted the printed and manuscript astrological works dedicated to him, if he thought these activities served no strategic purpose. In addition, through his enterprising ventures in printing annual prognostications Parron was important as an agent in the popularization of astrology that began in the middle of the fifteenth century and that ultimately led to a decline in the exclusivity of astrology in the century that followed. ${ }^{100}$

Besides Parron, there were a number of other English enthusiasts of the science of the stars who were in attendance at court. Of those close to

${ }^{95}$ Ibid., fol. $9^{\mathrm{v}}$.

${ }^{96}$ Plomer.

${ }^{97}$ Gunn, 1993, 44, notes that grooms and gentlemen ushers of the chamber received $£ 1$ or $£ 2$ a year, suggesting that Parron was at the bottom of the courtly hierarchy.

${ }^{98}$ Bodleian MS Selden Supra 77, fol. 4: De astrorum succincte vi.

${ }^{99}$ Rundle.

${ }^{100}$ Capp. 
the king, Richard Fitzjames is the most significant, and also the only one whose personal wealth made it possible for him to have invested in the production of Arundel 66. During his term as warden at Merton, Fitzjames liberally bestowed elements from his coat of arms, the family eagle and dolphin embowed, the episcopal miter and the academic pileus, throughout the college, including the stained glass of the chapel. ${ }^{101}$ According to Wood, Fitzjames extended this practice to other projects. On one occasion, when Fitzjames found a holy well neglected, he had an arch erected to protect it that incorporated the Fitzjames dolphin. ${ }^{102}$ In other reflections of Fitzjames's interest in astrology, Desiderius Erasmus (ca. 1467-1536) stated in a letter of 1521 that he regarded Fitzjames as "immoderately superstitious" and that he used the stars to calculate the best time to lay the foundation stone for a new college building, and used divination to recover lost property from Merton College. ${ }^{103}$

The most striking demonstration of Fitzjames's faith in astrology joined to the patronage of Henry VII is the zodiac archway in stone (figs. 9 and 10) that he constructed to connect the Warden's House with the hall at Merton College. The carving is of high quality and is in the same Burgundian style as the decoration deployed in Arundel 66 and in the two smaller illuminated manuscripts prepared by Parron for presentation to the king. There is nothing inherently astrological about the zodiac, which traditionally referred to time and the passing seasons and was for this reason often depicted in ecclesiastical settings, including the calendar. However, there is evidence that Fitzjames had more than this neutral reading of the zodiac in mind because of the chance survival of the horoscope that was used to determine the most propitious time for the construction of the zodiac arch as part of the Warden's Lodgings. ${ }^{104}$ This horoscope was originally part of a painted glass window that was seen by Erasmus when visiting Oxford from mid1499 to January 1500 on his first trip to England. ${ }^{105}$ Although the window

${ }^{101}$ Bott, 152-53, 97-203. Ibid., 190, notes that Merton College has no fewer than forty heraldic shields and badges for Fitzames and his family, of which more than half remain extant. Fitzjames also placed inscriptions and emblems in the nineteen books that can be identified as his in the college library. I thank Dr. Tim Ayers for alerting me to this reference. For a rich analysis of Fitzjames's contribution to the Merton stained glass, see Ayers.

${ }^{102}$ Clark, 1:389-90.

${ }^{103}$ Erasmus, 4:523 (no. 1211). Cited by Leader, 1:149-50.

${ }^{104}$ Bott, 202-03, and fig. 5 .

${ }^{105}$ McConica. 

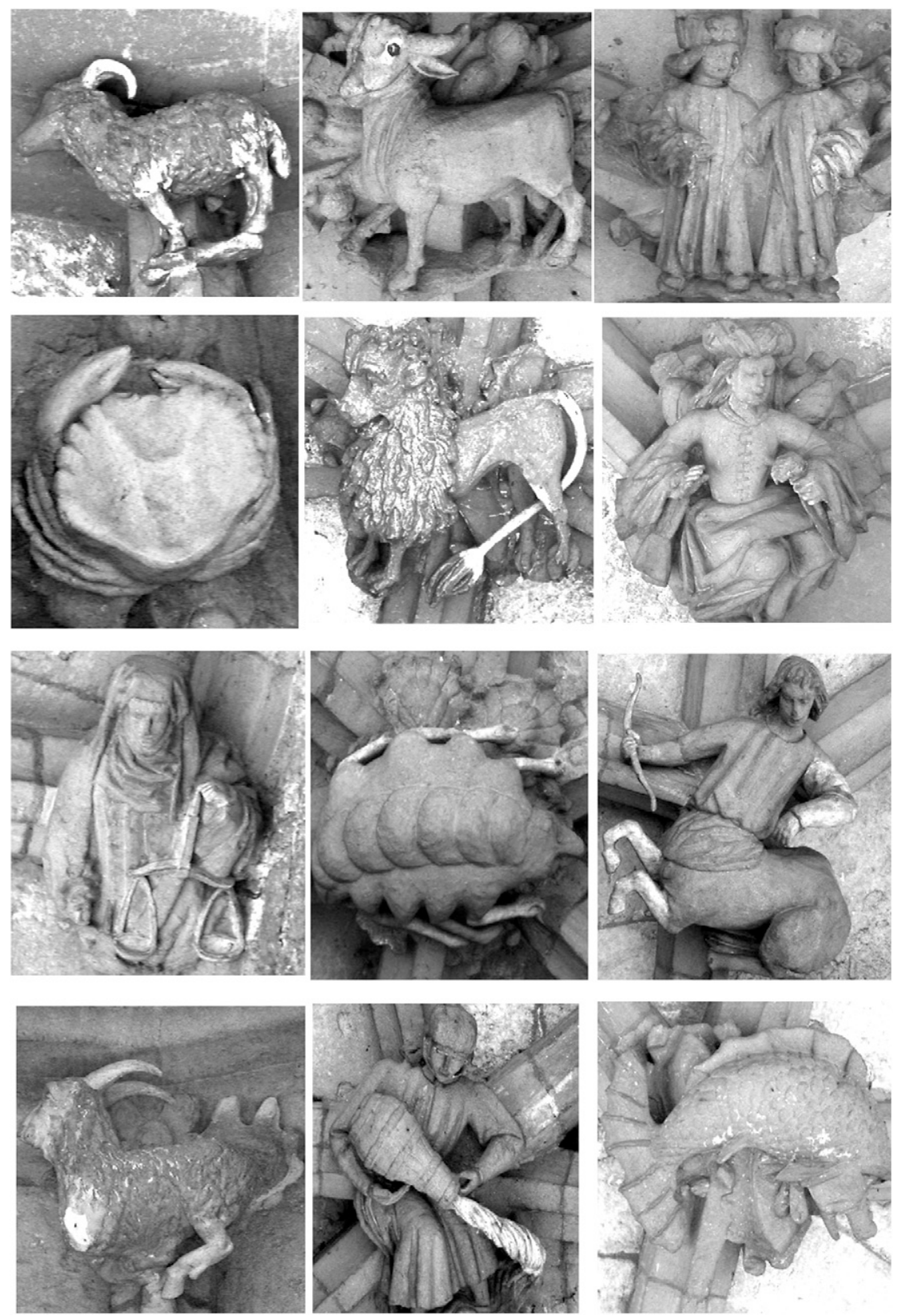

FIGURE 9. Details of the Zodiac Signs, Fitzjames Arch, from Merton College, Oxford. Courtesy of Merton College, Oxford. 


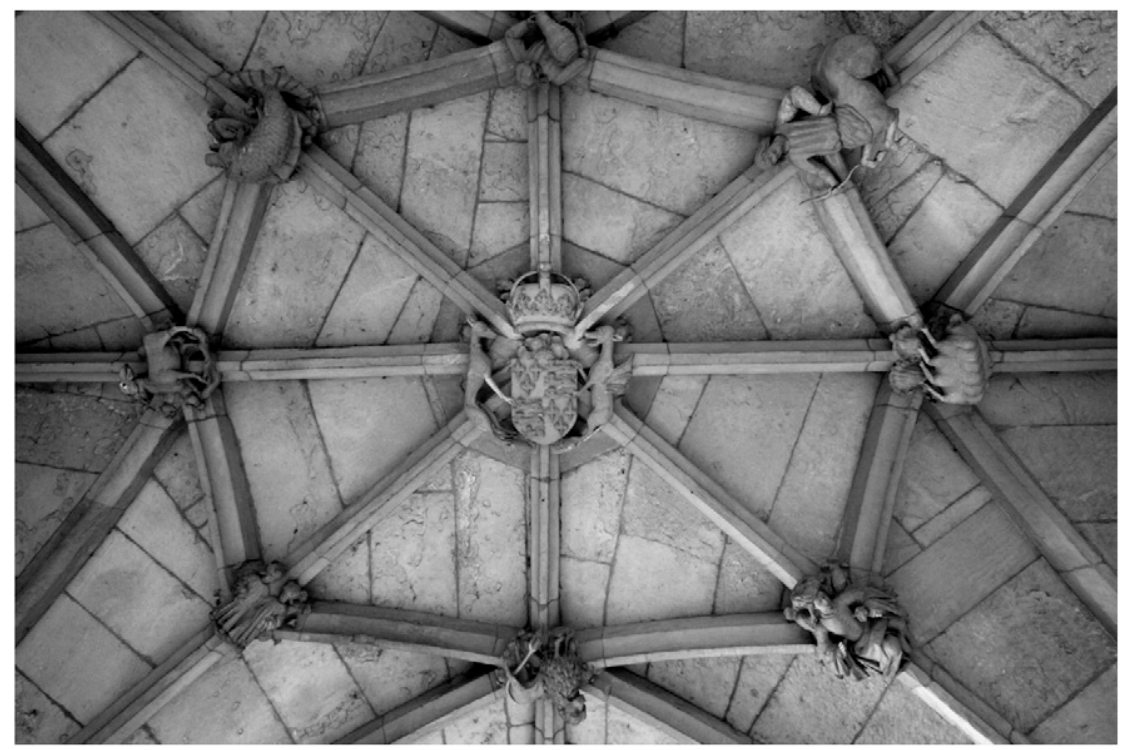

FIGURE 10. Arms of Henry VII and central signs, Fitzjames Arch, Merton College, Oxford. From the far left, signs are [Aries], Taurus, Gemini, [Cancer], Leo, Virgo, [Libra], Scorpio, Sagittarius, [Capricorn], Aquarius, Pisces. Signs in square brackets are not visible. Image by Holly Hayes/Art History Images. Courtesy of Merton College, Oxford.

has since been demolished, the horoscope was recorded by John Chalmers in 1601. ${ }^{106}$ The scheme can be summarized as follows:

\begin{tabular}{llllll}
\hline \hline Cancer 10 & Cancer 28 & Leo 16 & Virgo 5 & Libra 19 & $\begin{array}{l}\text { Sagittarius 2 } \\
\text { Jupiter: 1 } \\
\text { Scor. }\end{array}$ \\
\hline Capricorn 10 & Capricorn 28 & Aquarius 16 & Pisces 5 & Aries 19 & Gemini 2 \\
& & Venus: 15 ? & Merc.: 27 & Sol: 2 Ar. & Mars: Taurus \\
& & Pisc. & Sat.: 1? & 5 \\
& & Luna: 1? & Ar & \\
& & & &
\end{tabular}

Foundation horoscopes for the establishment of cities were well known in classical antiquity. Elections for the construction of buildings were also relatively common in Renaissance Italian architecture, when astrologers were able to take advantage of the ready availability of printed ephemerides. ${ }^{107}$ Examples from elsewhere in medieval Europe are extremely rare, though the

${ }^{106}$ Bott, 202-03, and fig. 5 .

${ }^{107}$ For a study of an election for the foundation of Peter's Basilica in Rome, see Quinlan-McGrath, 2001. 
theory of elections of this type was familiar from textbooks. Electing times for the construction of houses is discussed by Guido Bonatti in book 7, chapter 4 of his Introduction to astrology, the work that makes up the largest item in Arundel $66 .{ }^{108}$ Bonatti states that, when constructing houses, there is no need to consider the fixed stars, but only the planets. Hence, consideration should be given to the ascendant and its lord, the moon and the lord of the house in which it is located, and the planets that are joined to her, as well as the fourth house and its lord, and the second house and its lord. It was also important not to place any of the major signifiers sub terra (under the Earth, that is, the first six mundane houses of the scheme), which would prevent the construction of any building on the site for a long time. At this point, Bonatti cites a case of this kind with regard to a tower in his hometown of Forli. ${ }^{109}$ While these unfavorable aspects appear to have been avoided in the election represented in the Merton window, this appears to have been achieved at the expense of the real positions of the planets at the time it is supposed to represent. These bear little relation to the planetary positions for this date that might be obtained using contemporary astronomical techniques, or by consulting the printed Ephemerides published by Regiomontanus for this date. ${ }^{110}$ The latter included a handy crib of the aspects of the planets and revolutionized the practice of astrology. It can be assumed that if Fitzjames or the astrologer he employed to create this scheme had had access to a copy, they would have made use of them. While the error in the planetary positions may lie with Chalmers's transcription, such egregious mistakes were common in medieval astrology, and sometimes occurred as a result of borrowing schemes from books rather than calculating them for the relevant occasion. ${ }^{111}$

Another courtier who promoted the cause of astrology at the Tudor court was the Welsh physician Lewis Caerleon. ${ }^{12}$ Caerleon studied

\footnotetext{
${ }^{108}$ Bonatti, fol. 202.

${ }^{109}$ Ibid. For a full translation and explication of the astrological points made by Bonatti, see Dykes.

${ }^{110}$ Regiomontanus, fol. $312^{\mathrm{r}}-313^{\mathrm{r}}$. This gives the planetary positions for 12 March 1497 as: Sun $1^{\circ} 26^{\prime}$ Ar; Moon $7^{\circ} 54^{\prime}$ Pisces; Mercury $12^{\circ} 10^{\prime}$ Aries; Venus $5^{\circ} 1^{\prime}$ Taur; Mars $26^{\circ} 43^{\prime}$ Sagittarius; Jupiter $13^{\circ} 6^{\prime}$ Sagittarius; Saturn $12^{\circ} 38^{\prime}$ Aries. This data is for Nuremberg, and adjustments would have to be made for the time and place (Oxford) of the Merton scheme, but these would not compensate for the wild variations in the real positions of the planets. The only data that is even remotely correct is that for the position of the sun at 2 Aries.

${ }^{111}$ For two examples of this practice, including the textbook example in the treatise $D e$ urina non visa by William Anglicus, see Carey, 2008.

${ }^{112}$ Kibre, 1952.
} 
medicine at Cambridge University, but is said by one biographer to have had most of his education at the University of Padua. ${ }^{113}$ Padua, the major studium of the Venetian republic, was an important university for English students, who went there to study law, medicine, astrology, natural philosophy, and the sophisticated mastery of classical Latin style that marked the humanist. ${ }^{114}$ At Padua, astrology was studied as an integral part of medicine, and it was common for astrologers to be trained in both arts. On his return, Caerleon entered a close relationship with the Tudor party, even spending time in the Tower of London at the height of the conspiracy to topple the Yorkist regime of Richard III. His loyal service was rewarded in 1488 when he was made a knight of the king's alms at St George's Chapel, Windsor, with residence in the outer ward. It is intriguing to consider if Caerleon had some connection with the painted glass horoscope of Edward III, now in the north window of the annex to Edward IV's chantry, which once formed part of the now-demolished canons' houses. ${ }^{115}$

Caerleon demonstrates that there was an interest in earlier English astronomical and astrological writing at the Tudor court. He was an antiquarian who collected and copied astronomical tables, especially those of astronomers associated with Merton College, and he owned copies of the works of Richard of Wallingford, Simon Bredon, John Holbroke, John Killingworth, John Somer, and John Walter. ${ }^{116}$ These have survived in a number of rather disorganized manuscripts in his own hand, together with his own attempts at eclipse calculations. ${ }^{117}$ In relation to Arundel 66, it is significant that Caerleon made a copy of the Tables of John Killingworth with its canon, which makes up the first two items in the manuscript. ${ }^{118}$ (These are the ones North called the "most sumptuous astronomical tables ever penned"). ${ }^{119}$ Clearly, Caerleon also thought highly of them. Caerleon

${ }^{113}$ William Owen Pughed, cited by Snedegar.

${ }^{114}$ Woolfson, 5, notes that Padua was the most favored foreign university for English students between 1485 and 1603. One of them was Thomas Linacre, who also served as tutor to Henry VIII: see Maddison, Pelling, and Webster.

${ }^{115}$ Jefferson, cited by Wayment, 57-58, fig. 51.

${ }^{116}$ Snedegar.

${ }^{117}$ London, British Library, MS Royal 12 G I; London, British Library, MS Sloane 1697; California State Library, San Francisco, MS 8, art. 4; Cambridge, University Library, MS Ee.3.61 (hereafter, Cambridge MS Ee.3.61); Cambridge, St John's College, MS 41.

${ }^{118}$ For the Caerleon copy, see London, British Library, MS Sloane 407, fol. 57.

${ }^{119}$ North, 2004. 
also made a copy of the "Tables of Directions of Duke Humphrey," 120 which indicates that he was aware of at least one of the scientific works associated with Humphrey, Duke of Gloucester. He may therefore also have known of the other astronomical and geomancy tables associated with Duke Humphrey that appear in Arundel 66 (items 3, 11).

\section{Henry ViI and the Astrological Renaissance}

The activities of Parron, Fitzjames, and Caerleon reflect the increasing interest and sophistication with which astrology was regarded in the $1490 \mathrm{~s}$ at the highest level of society and by certain members of the learned professions. With its glamorous Italian practitioners as well as local English enthusiasts and patrons, astrology enjoyed sufficient standing to be incorporated simultaneously into the arts and politics of the court.

It is reasonable to argue that there were political advantages to his cultural receptiveness to astrology, which appears to have been at its height during the prolonged diplomatic negotiations leading to the marriage of Prince Arthur to Katherine of Aragon. Negotiations for the marriage began almost as soon as Arthur was born. They formed a central role in Tudor diplomacy and were not finally settled until 1500. Meanwhile, the couple were betrothed and married by proxy, the former in 1497 and the latter in 1499 and 1500, before Katherine arrived in England on 2 October 1501.

The most important evidence for an association between astrology and the Spanish alliance comes from the great pageants arranged in London for the reception of Katherine of Aragon. The designer of the London pageants is not known and our knowledge of them comes solely from the descriptions of three spectators, one of whom was probably a herald commissioned by Henry VII to record the event as completely as possible. This is the source followed here. ${ }^{121}$ Anglo called the event "the most original and complex essay in the pageant medium ever presented in England," and provides a detailed discussion of the event. ${ }^{122}$ The pageant designer appears to have decided that astronomy and astrology would provide a central frame of reference for both Princess Katherine, descendant of the scholar-king of Aragon, and Prince Arthur, namesake of the ancient King of Britain, and there are extensive celestial allusions in four of the six pageants to the

\footnotetext{
${ }^{120}$ Tables of directions were used to raise the boundaries of the houses when casting a horoscope for a particular place and time. For Caerleon's copy, see Cambridge MS Ee.3.61, fol. 108 .

${ }^{121}$ London Pageants.

${ }^{122}$ Anglo, 1963, 55; Anglo, 1997.
} 
constellations associated with both the bride and groom. In the first, the pageant of the Trinity, Saint Ursula, and Saint Catherine, the princess is honored by invoking "Kateryn of the Courte celestiall," that is, Saint Catherine; Arthur is referred to as both a noble and valiant historical king and "the noble sign in heven, / Beautie of the northe, with bright sterres seven." This rhyming reference to the constellation Arcturus is then augmented by suggesting that Saint Ursula was near to the constellation of "Minor Ursa / That otherwise is calid Synosura / Sett fast by Arthure, with other sterres bright / Gevyng great compforte to travellours by nyght." ${ }^{123}$ It is difficult to know if the crowd would understand the allusions, but all would be made plain on reference to the named constellations as they were depicted in Arundel 66 (fols. 33, 34). The astronomical theme is also invoked in the second pageant: the final lines invite the princess to consider "your kynnsman King Alfons / Which of austronomy was the very well."124

King Alfonso returns as a major figure in the fourth pageant with a speech prophesying the coming of the wedding between the realms of England and Spain, and proving it would be propitious by an elaborate astrological calculation addressed to Princess Katherine, whom he calls "Daughter." Katherine is associated not just with the Little Bear, but with Hesperus (Venus), while Arthur continues to be identified with Arcturus: "Doughter, the sonne, signifiour of Kinges, / Enterying the Sagittary, and his triplicate / To whose conjunction approximate is / Hesperus and Arthure, the signifiour, as we se / For the more parte in the same house to be. / Loo, Lady Kateryne, these tokenes signifie / What dignyte ye shall opteyne, where and why." 125 There follow four more astrological verses, assuring Katherine that as queen she has entered her rightful "Land of Sagittary," England, the sign under which Prince Arthur had been born, in the fiery triplicity of the Lion, and that all the celestial signs indicated that theirs would be a prosperous marriage: "To whose seid signifior the bodies celestiall / Stand very benyvolent, and frendly derecte, / And eke your owne sterre Hesperus especiall / Hath of ev'rych planete right prosperous effecte / To folow upon yo' noble marriage / To Prince Arthure's worthy personage." 126 The pageant of the Moon concluded with the determination that "Astronomer, Philosopher and Devyne" all lent their blessing to the nuptials.

\footnotetext{
${ }^{123}$ London Pageants, 262.

${ }^{124}$ Ibid., 266.

${ }^{125}$ Ibid., 270.

${ }^{126}$ Ibid.
} 
The astronomical theme continues in the fourth pageant, which was in Cheapside. This displayed a wheel painted with clouds under which there was Saint George's cross, a red sword, and two astronomers with their instruments, one with a "triangle" and another with a quadrant, "havyng their speculation to the bodies above." Above there was a painting of God the Father with the angels and there was a representation of the other heavenly bodies described by the herald as follows: "In the brede of this whele ther were meny dyvers figures, sum of berys, sume lyons, sum hors, sume wormys, sume fisshis, sum mermeyds, sume bullis, sume virgyns, sume naked men, sume ramys stikked full of sterrys, as they be appropred and namyd in bokys of astronomy, havyng lynys, sume red, sume whight, deducte from iche sterre, planet, and signe, and after the aspect that naturally iche of them hath unto other." ${ }^{127}$ This could serve very well as a description of the miniatures of the constellations in Arundel 66, whose positions on fol. $47^{\mathrm{r}}$ are said to have been "verified by the astrologers of Lord Alfonso the illustrious king of Spain and verified in Oxford in the year of the lord 1449 by the astrologers of Humphrey duke of Gloucester." Above this fantastic scene, in the sphere of the sun, rode "the Prince of Englond shewying and declarying his fatall disposicion and desteny." ${ }^{128}$ The pageantry continued for a month. After the wedding in Saint Paul's on 14 November there was a great feast, a more intimate dinner with the king's mother, Margaret Beaufort, dubbing of Knights of the Bath, a tournament, more feasts and jousting, a trip in a barge to Westminster, hunting, and yet more dancing and feasting to bid the Spanish party farewell. Tragically, in the midst of the ongoing festivities, the groom was struck by illness. The herald records Prince Arthur's decline and pious death with the same care and detail as he described the astrological festivities that led up to it. ${ }^{129}$

The arrival of a Spanish princess in England reminds us that there is an international context to the Tudor Renaissance and what appears to have been the cautious investment in astrology by the king and his courtiers. Arundel 66 may be the most sumptuous scientific book produced for any medieval or Renaissance patron in England, but it does bear comparison with astrological and scientific manuscripts produced for the adornment

${ }^{127}$ Ibid., 273. For reproductions of some of these constellations, see the collection of images on the British Library online catalogue, including the Great Bear and Little Bear (fol. 33), Draco (fol. 33 ${ }^{\mathrm{v}}$ ), Opiuchus (naked man: fol. 36 $6^{\mathrm{v}}$ ), Dolphin (fol. $37^{\mathrm{v}}$ ), Equus prior (fol. 38), Ceta (Whale: fol. 43ำ), Fluvius (naked woman: fol. 44).

${ }^{128}$ London Pageants, 273.

${ }^{129}$ Ibid., 319-23. 
of ducal and princely libraries in both the Islamic and Latin worlds. ${ }^{130}$ Indeed, it emerges from a long tradition of preparing works of astronomy, astrology, cosmology, and the calendar for a royal and courtly audience. Such works were commonly illustrated, particularly books of constellations, astronomical tables, astrological compilations, and encyclopedias. ${ }^{131}$ Astrology provided the central legitimizing discourse for the Abbasid caliphs (750 to 1258), who spearheaded the translation movement of Greek scientific works into Arabic and the creation of the astrological corpus that formed the basis for astrological practice in the Latin West. ${ }^{132}$ Alfonso X of Castile appears to have been the first medieval king to have commissioned translations of scientific works into the vernacular language of his people using collaborative teams of translators. His name continued to be attached to later astronomical works, including the edition of the Alfonsine Tables that was produced at the University of Paris in the 1320s. Images were incorporated into the Alfonsine corpus from an early date. ${ }^{133}$ As a royal work, this was prepared in a number of grand illuminated editions, for example, Berlin, Staatsbibliothek Preuß. Kulturbesitz, Kupferstichkabinett, 78 D 12, which has fifty full-page miniatures and is illuminated in both silver and gold. ${ }^{134}$ In numerous artistic forms the cosmos was depicted mythologically, figuratively, and practically, as the potential domain of the prince. The precise knowledge of the celestial bodies that was made possible by the development of more accurate instruments and tables was incorporated into architectural forms (both civic and domestic), illuminated books, and the rituals and pageants that marked events such as royal births, deaths, and coronations. ${ }^{135}$

When considering the function of the illuminated book of constellations and other astronomical tables in Arundel 66, it is relevant to link these to the Renaissance fascination with the creation of star maps that might be incorporated into architectural spaces. ${ }^{136}$ There was already a tradition of incorporating the figures of the signs of the zodiac into arches of churches. From the 1420s this earlier tradition was rendered in much more sophisticated scientific forms, with accurate renditions of the positions of the heavenly bodies as calculated by court astronomers and astrologers and using the latest

\footnotetext{
${ }^{130}$ Kibre, 1946.

${ }^{131}$ Blume; Bober, Saxl, and Meier.

${ }^{132}$ For translation as a legitimating political strategy for the early Abbasid caliphs, see Gutas, 28-29, 108-10.

${ }^{133}$ Cárdenas, 18.

${ }^{134}$ Alfonso X el Sabio.

${ }^{135}$ Blume.

${ }^{136}$ Kanas; Whitfield, 1995.
} 
versions of data from printed astronomical tables, such as the high quality editions prepared by Erhard Ratdolt from the work of Regiomontanus. The first attempts to do this were one-off commissions, such as the representation of the Northern sky over Florence on 4 July 1442 that was painted by Giuliano d'Arrigo on the inner dome (scarsella) of the chapel of the Old Sacristy in the church of San Lorenzo, possibly on the basis of calculations of the mathematician and geographer Paolo dal Pozzo Toscanelli (1397-1482), who was a friend of Brunelleschi. ${ }^{137}$ The thirst for accurate knowledge of the stars is reflected in the astrological vaults that were commissioned and executed for princely domains in the fifteenth and sixteenth centuries. ${ }^{138}$ These wider European trends in the development of art, science, and astrology can be evoked as the contemporary context for Arundel 66, the zodiac archway and horoscope of Richard Fitzjames, and the astrological pageants that welcomed Katherine of Aragon to the city of London.

Finally, we should not forget the political dangers that faced astrologers operating at the highest level of court society throughout the fourteenth and fifteenth centuries. ${ }^{139}$ Not all parts of astrology were seen as equally legitimate and, like other courtiers, astrologers could be brought down by politically motivated accusations of heresy and witchcraft. ${ }^{140}$ William Parron was careful to demonstrate his theological orthodoxy, both in the defense of astrology that he wrote for Henry VII and in his respect for ecclesiastical authority. The memory of the show trials of Joan of Navarre in 1419, or of Eleanor Cobham, together with the clerks Roger Bolingbroke and Thomas Southwell and Margery Jourdemayne, in 1441, is unlikely to have been entirely extinguished by the reign of Henry VII. ${ }^{141}$ There is abundant evidence for the unsuccessful attempt made by the French astrologer, Symon de Phares (ca.1440-ca.1499), a contemporary of William Parron who was favored at the court of Charles VIII of France, to avoid impeachment by an ecclesiastical court at the University of Paris. ${ }^{142}$ The lengthy defense of astrology that he wrote failed to win his case and his magnificent library of astrological books, which formed the basis for a biographical history of astrology, was confiscated. We do not know why

${ }^{137}$ Reproduced in Zuffi and Navellone, 86.

${ }^{138}$ Lippincott, 1985 and 1990; Quinlan-McGrath, 1984 and 1995.

${ }^{139}$ Freeman; Griffiths; Jones; Ralley, 2010; Smoller; Veenstra.

${ }^{140}$ Jones. See Veenstra for the Burgundian context of that by Laurent Pignon, Contre les devineurs (1411). The most celebrated treatise on astrology was Pico della Mirandola's Disputationes contra astrologiam divinatricem published in 1494 and possibly known to Parron.

${ }^{141}$ Carey, 1992, 138-53; Ralley, 2010; Griffiths.

${ }^{142}$ Boudet, 1997-99; Wickersheimer and de Phares. 
Parron left the court of Henry VII, but his position was inherently vulnerable and he may have wisely decided it was a good time to seek patronage elsewhere.

\section{CONCLUSION}

Arundel 66 is an important manuscript that provides critical evidence for the place of astrology at the early Tudor court. There can be no certainty about the donor of this fine book, though a case can be made for the ecclesiastical courtier Richard Fitzjames. Despite this, Arundel 66 was not an isolated artifact or an eccentric gift for the use of Henry VII. It was prepared at the same time as a number of other astrological projects under Tudor patronage, or by courtiers close to the royal household. These include the astrological pageants for Katherine of Aragon, the zodiac arch at Merton College, Oxford commissioned by Richard Fitzjames, and also the antiquarian collecting of English astronomical and astrological works by Lewis of Caerleon. Like other fine illuminated scientific manuscripts, Arundel 66 may have been conceived as a tool for the education of a prince in the science of the stars and in the prophecies that related to the Tudor regime. That prince may have been Arthur, Prince of Wales, whose coming marriage to Katherine of Aragon, descendant of Alfonso X of Castile, the greatest of all medieval scholar-princes, was being contemplated at the time it was compiled. The deaths of both Prince Arthur and Queen Elizabeth, and the loss of confidence in the capacity of the professional astrologer to forecast catastrophe that may have followed these sad events, is likely to have led in turn to an eclipse in the standing of astrology at court. Arundel 66 demonstrates that astrology contributed to the world of the English Renaissance of the early Tudors in a way generally seen as more characteristic of the courts of Northern and Southern Continental Europe. 


\section{Appendix}

London, BL Arundel 66: Description of Contents: ${ }^{1}$

$1^{\mathrm{r}}$. Blank

[1] $1^{\mathrm{v}}-2^{\mathrm{v}}$. Canons to Oxford tables of John Killingworth.

Rub. "Tabulas Kelyngworth Oxoniensis. Canones tabularum Oxoniensium facilis composicionis Almanak et capitul $u \mathrm{~m}$ primu $m$ declarans occasione $m$ colligendi has tabulas." Inc. "Multum conferre dinoscitur non solum astronomis." Expl. "cum nadir solis et loco lune." Col. "Expliciunt canones tabularum facilis composicionis Almanak secundum modum vniversitatis Oxoniensis et Incipiunt tabule que dicuntur Kelyngworth.” TK 0891G.

[2] $3^{\mathrm{r}}-32^{\mathrm{r}}$. John Killingworth, Astronomical tables.

Rub. "Tabule que dicuntur Kelynworthe." Inc. "Prima tabula revolucionis lune." Expl (fol. 32 ${ }^{\mathrm{r}}$ ). "Libra."

$30^{\mathrm{v}}, 32^{\mathrm{v}}$. Blank.

[3] $33^{\mathrm{r}}-47^{\mathrm{r}}$. Faces of the constellations.

Rub. "Facies celi septentrionis. Ffacies celi cum gradibus et locis stellarum. Constellaciones formarum septentrionalium a zodiaco celi. Stellacio urse minoris et dicitur cinosura." Inc. "Illa que est super extremitate caude." Col. (fol. $47^{\mathrm{r}}$ ). "Explicit tabula stellarum fixarum secundum quod sunt in Ymaginibus signorum extacta a ptholoemo diccione .6. ${ }^{\mathrm{a}}$ et .7. Almageste et verificata per astrologos domini Alfonsi illustris regis hispanie anno domini 1449 et verificata Oxoniensis anno domini 1449 per astrologos humfredi ducis gloucestrie. TK 0548K. See also TK 0659I Prosdocimo de' Beldomandi, Tabulae; Northern and southern constellations.

$47^{\mathrm{v}}$. Blank

[4] $48^{\mathrm{r}}-52^{\mathrm{v}}$. Index to Guido Bonatti, Introduction to astrology.

Rub. "Liber introductorius ad judicia stellarum." Inc. "Tractatus primus ad ostendendum vtilitatem quam possimus seu de astronomia et iudicijs."

$53^{\mathrm{r}}-53 \mathrm{a}^{\mathrm{v}}$. Blank. (There are two folios numbered as 53.)

$53 \mathrm{~b}^{\mathrm{r}}-248^{\mathrm{r}}$. Guido Bonatti, Introductorius ad iudicia stellarum.

Rubric inc. "In nomine domine Amen. Incipit liber Introductorius ad iudicia stellarum." Prologue inc. "In nomine domini nostri Jesu cristi." Text inc, "Anima

${ }^{1}$ Abbreviations: Rub. Rubric; Inc. Incipit; Expl. Explicit; Col. Colophon; pr printed by; TK L. Thorndike and P. Kibre, A Catalogue of Incipits of Mediaeval Scientific Writings in Latin (London, 1963). Numbers in square brackets refer to the numeration in the online BL catalogue entry by Forshall (1834). Text in italics expand contractions and abbreviations in the manuscript.

${ }^{2}$ Both dates appear to be errors. The correct date for the Alfonsine data is 31 May 1252. The data for Humphrey, Duke of Gloucester (d. 1447) is listed in the table on the same folio as 1440 . 
est nobilius quo repetitur in homine." Expl. (fol. 249 $)$. "Saturno applicans ymbres multiplices inducit." TK 0097B. The index and text is the same as the first printed edition by Ratdolt, Augsburg, 26 March 1491 (ISTC No.: ib00845000; Klebs 195.1; IAL B757). It differs from that printed in Venice, 1506.

$186^{\mathrm{r}}-186^{\mathrm{v}}, 248^{\mathrm{v}}-249^{\mathrm{v}}$. Blank

$249^{\mathrm{r}}$. Colophon

Finitur hic liber Gwuydonis bonacti de forlivio

Anno Christi 149030 die Junij ho ${ }^{\text {ra }} 12 \mathrm{~m}^{\mathrm{a}} 24^{\mathrm{a}}$ per me

Johannem Wellys compositus et renovatus et anno

Henrici regis $7^{\mathrm{i}} .4 .^{\text {to }}$ pontificatus sanctissimi in Christo patris

nostris Innocentij pape $4^{\text {to }} 5^{\text {to } 3}$

[5] $250^{\mathrm{r}}-264^{\mathrm{r} .}$ Alfonsine Tables (extracts).

Rubrics. "Tabula com $m$ unis ad extrahendum omnes eras bisextiles et ad extrahendo incognita et cognita (fol. $256^{\mathrm{r}}$ )." "Tabula differenciarum vnius regni ad aliud et nomina Regnum atque cuiuslibet ere cognite (fol. 256 v).” TK 1552a.

$264^{\mathrm{r}}-266^{\mathrm{r}}$. Canons to Alfonsine Tables (extracts).

Inc. "Inuentis centris et argumentis medijs alicuius planete." Expl. (fol. 266 ${ }^{\mathrm{r}}$ ). "vtrum sit de longitudine longiori vel propriori." TK 775.

[6] $267^{\mathrm{r}}-268^{\mathrm{v}}$. Prophecies of Merlin (Geoffrey of Monmouth, Historia regum Britanniae)

Rub. "Libellus Merlini Ambrosij in prophesia." Prologue Inc. "Coegit me Alexander Lincolniensis." Extracts Inc. "Prophetia Merlin Ambrosii. Sedente igitur vortegirno rege britonum." Expl. (fol. 268v) "confligent venti diro sufflamine. et sonitum inter sidera conficient. Explicit.” Historia regum Britanniae, book. VII, ch. iii.

[7] $268^{v}$. Table of Cities with Longitudes and Latitudes (incomplete).

[8] $269^{\mathrm{r}}-277^{\mathrm{r}}$. Alpharinus, filius Abrahe. Judaeus, De judiciis geomantie, tr. Plato of Tivoli.

Rub. inc. "In nomine domini nostri Jheusi Christi incipit Liber sciencie arienalis de iudicijs geomansie ab alpharino filio abrahe iudeo editus et a platone de hebreico sermone in latinum translatus. Sequuntur nomina figurarum cum figuris geomansie. Populus etc." Text inc. "Fortuna maior in prima domo." Expl. (fol. 277 ) "et est ibi cogitatus niultus.” TK 568.

[9] $277^{\mathrm{v}}-287^{\mathrm{r}}$. Canons to Geomancy Tables of Duke Humphrey.

Rub. "Tabulas humfridi ducis glowcestris in iudiciis artis geomancie." Canon inc. "Antequam procedatur ad iudicum alicuius questiones proposite." Expl. (fol. 278v) "non dicitur aliquam VIIii here." TK 109.

$278^{\mathrm{v}}-284^{\mathrm{v}}$. Geomancy Tables of Duke Humphrey.

${ }^{3}$ The number 4 has been deleted and corrected to 5 at this point. 
Rubrics include: [T] abula ostendens significata duodecim domorum." Inc. "A. De acquisicione 2a , De anno fertili 5a 10a 11a." Expl. (fol. 279") "U . . De Venis 8, De ventis 10." [T] abula ostendens significata planetarum et figurarum eis attributarum. (fol. 279'); [T] abula ostendens proprietates atque significationes conueniencias et differencias .16. figurarum (fol. $281^{\mathrm{v}}$ ); Tabula ostendens proprietates ipsarum figurarum in natura singulari (fol. $282^{\mathrm{r}}$ ); Tabula ostendens dignitates ipsarum figurarum (fol. $282^{\mathrm{r}}$ ); [T] abula ostendems nat uram et proprietates om niu $m$ figurarum quas contrahunt $\left(\right.$ fol. $283^{\mathrm{v}}$ ); Tabula conuenienciarum et similitudinem ipsarum sedecim (fol. $284^{\mathrm{v}}$ ); Tabula ostendens intenciones communes querentis per qualitates figurarum [includes square diagram of houses, qualities (ignis, aer, aqua, terra), and "intentions" (animam, prelatas, corpus etc) (fol. 286 ). Expl. (fol. 287 $7^{\mathrm{r}}$ "de quo laudetur deus omnipotens. Amen. Explicitur tabulas humfridi ducis glousestrie." TK 109.

[10] $287^{\mathrm{v}}$. Table of the planets with the signs and their significations.

[11] $288^{\mathrm{r}}-290^{\mathrm{v}}$. Robert of Bridlington, Vaticinia.

Inc. "Febribus infectus: requies fuerat mi hi lectus. Expl. (fol. $290^{\mathrm{v}}$ ). "Ad mortem tendo. morti mea carmina pendo. Expliciunt.” TK 550. Thomas Wright, Political Poems and Songs Relating to English History, RS, vol. 1 (London 1859), pp. 128-211.

[12] $290^{\mathrm{v}}$. Robert of Bridlington, Verses.

Inc. "Lilia terna dies libre." Expl. "Imperium mundi: suscipiet heremita."

[13] $291^{\mathrm{r}}-291^{\mathrm{v}}$. St Bridget or Birgitta of Sweden, Visiones (extracts).

Rub.: "Visiones sancte Brigitte vidue filie regis Swavie de regibus Anglie et Francie." Inc. "Orante Christi sponsa vidit in visione qualiter beatus Dionisius orabat pro regno francie ad virginem mariam." Expl. (fol. 291 v) "bonam pacem. Hec om nia in capitulo .203. et .228. et in alijs locis libri quarti et quinti."

[14] 291 ${ }^{\mathrm{v}}$. Merlin Silvestris, Prophecies.

Rub: "Hec prophetia Merlin Siluestris Anglorum Edwardo regi secundo nominis." Inc. "Arbor fertilis a proprio trunco decisa ad spacium integrum a radice propria separatur." Herbert, J. A. and H. L. D. Ward, Catalogue of Romances in the Department of Manuscripts in the British Museum, 3 vols. (London, 1883), I.295. Another copy BL Additional 40007, fol. 41 ${ }^{\mathrm{v}}$.

[15] 291 . Four Short Prophecies.

(i) Inc. "Aliud. Sicut rubeum draconem albus expellet sic niueum eiciet tenebrosus; Draco teterrimus et terribilis aduolabit." Ward \& Herbert, Catalogue of Romances, I.296. Another copy, see BL, Cott. Tib. A. ix, fol. $5^{\text {rb }}-5^{\text {vb; }}$

(ii) [Prophecy attributed to $S$. Thomas Becket] Inc. "Lilium regnans in nobile parte mundi manebit."

(iii) Inc. "Cesaris imperium: per tempora longa latebit."

(iv) Inc. "Brutus finitur: per eum missus reperitur." 


\section{Bibliography}

\section{Archival Sources}

Berlin, Staatsbibliothek Preuß. Kulturbesitz, Kupferstichkabinett, 78 D 12.

California State Library, San Francisco, MS 8.

Cambridge, St John's College, MS 41.

Cambridge, University Library, MS Ee.3.61.

London, British Library, MS Arundel 66.

London, British Library, MS Royal 12 B VI, also called Liber de optimo fato.

London, British Library, MS Royal 12 G I.

London, British Library, MS Royal 16 F II.

London, British Library, MS Royal 20 E I-E VI, also called Chroniques de France. London, British Library, MS Royal 19 C VIII, also called Imaginacion de vraye noblesse.
London, British Library, MS Sloane 407.

London, British Library, MS Sloane 1697.

Oxford, Bodleian Library, MS Bodley 614.

Oxford, Bodleian Library, MS Laud Misc. 644.

Oxford, Bodleian Library, MS Selden Supra 77, also called Libellus de astrorum succincte vi fatali.

Paris, Bibliothèque nationale, MS latin 6276, also called Liber de optimo fato.

Paris Bibliothèque nationale, MS latin 1196, also called The Prayerbook of Charles d'Orléans.

Yale University, Beinecke Rare Book and Manuscript Library, MS Mellon 25.

\section{Printed Sources}

Alexander, Michael Van Cleave. The First of the Tudors: A Study of Henry VII and His Reign. Totowa, NJ, 1980.

Alfonso X el Sabio. Tablas de las constelaciones de Alfonso X el Sabio. Valencia, 2006.

Allen, Don Cameron. The Star-Crossed Renaissance: The Quarrel about Astrology and Its Influence in England. London, 1966.

Anglo, Sydney. "The London Pageants for the Reception of Katharine of Aragon: November 1501." Journal of the Warburg and Courtauld Institute 26 (1963): 53-89.

-. Images of Tudor Kingship. London, 1992.

Spectacle, Pageantry, and Early Tudor Policy. $2^{\text {nd }}$ ed. Oxford, 1997.

Armstrong, C. A. J. "An Italian Astrologer at the Court of Henry VII." In Italian Renaissance Studies: A Tribute to the Late Cecilia M. Ady, ed. E. F. Jacob, 433-54. London, 1960.
Ayers, T. The Medieval Stained Glass of Merton College, Oxford. Oxford, 2011.

Azzollini, Monica. "Reading Health in the Stars: Politics and Medical Astrology in Renaissance Milan." In Horoscopes and Public Spheres: Essays on the History of Astrology, ed. Günther Oestmann, H. Darrell Rutkin, and Kocku von Stuckrad, 183-206. The Hague, 2005. Backhouse, Janet. "Founders of the Royal Library: Edward IV and Henry VII as Collectors." In England in the Fifteenth Century: Proceedings of the 1986 Harlaxton Symposium, ed. Daniel Williams, 23-41. Woodbridge, 1987.

- "Illuminated Manuscripts Associated with Henry VII and His Immediate Family." In The Reign of Henry VII: Proceedings of the 1993 Harlaxton Symposium, ed. Benjamin Thompson, 175-87. Stamford, 1995.

_ . "Charles of Orléans Illuminated." In Charles d'Orléans in England 
(1415-1440), ed. Mary-Jo Arn, 15763. Cambridge, 2000.

Baumgartner, Frederic J. Louis XII. New York, 1994.

Bevan, Bryan. Henry VII: The First Tudor King. London, 2000.

Birch, Walter de Gray, and Henry Jenner. Early Drawings and Illuminations: An Introduction to the Study of Illustrated Manuscripts. London, 1879.

St. Birgitta of Sweden. Revelaciones. Book 4. Ed. Hans Ailia. Uppsala. Online edition: http://www.umilta.net/bk.html (accessed 29 September 2011).

Blume, Dieter. Regenten des Himmels. Astrologische Bilder in Mittelalter und Renaissance. Berlin, 2000.

Bober, Harry, Fritz Saxl, and Hans Meier. Verzeichnis astrologischer und mythologischer illustrierter Handschriften des lateinischen Mittelalters: III. Handschriften in englischen Bibliotheken. 2 vols. London, 1953.

Bonatti, Guido. Decem continens tractatus Astronomie. Ed. Johannes Angeli. Augsburg, 1491. Online edition at Bayerische Staatsbibliothek (BSB), München: http://nbn-resolving.de/ urn:nbn:de:bvb:12-bsb00025600-0 (accessed 29 September 2011).

Bosanquet, E. F. English Printed Almanacks and Prognostications: A Bibliographical History to the Year 1600. London, 1917.

Boudet, Jean-Patrice, ed. Simon de Phares: Le Recueil des plus célèbres astrologues de Simon de Phares. 2 vols. Paris, 199799.

- Entre science et nigromance. Astrologie, divination et magie dans l'Occident médiéval, $X I I^{e}-X V^{e}$ siècle. Paris, 2006.

Bott, Alan. The Heraldry in Merton College, Oxford. Oxford, 2001.

British Library, Online Catalogue of Illuminated Manuscripts. http://www. bl.uk/catalogues/illuminatedmanuscripts/ (accessed 29 September 2011).
Buettner, Brigitte. "Past Presents: New Year's Gifts at the Valois Courts, ca. 1400." The Art Bulletin 83 (2001): 598-625.

Burnett, Charles. "Astrology.” In Medieval Latin: An Introduction and Bibliographical Guide. Ed. A. C. Mantello and A. G. Rigg, 369-82. Washington, DC, 1996.

Capp, Bernard Stuart. Astrology and the Popular Press: English Almanacs 15001800. London, 1979.

Cárdenas, Anthony J. "The Complete Libro del Saber de astrología and Cod. Vat. Lat. 8174." Manuscripta 22 (1981): $14-22$.

Carey, Hilary M. Courting Disaster: Astrology at the English Court and University. London, 1992.

_- "Medieval Latin Astrology and the Cycles of Life: William English and English Medicine in Cambridge, Trinity College Ms O.5.26." In AstroMedicine: Astrology and Medicine, East and West, ed. Anna Akasoy, Charles Burnett, and Ronit YoeliTlalim, 33-74. Florence, 2008.

-. "Astrology in the Middle Ages." History Compass 8 (2010a): 888-902. . "Judicial Astrology in Theory and Practice in Later Medieval Europe." Studies in History and Philosophy of Biological and Biomedical Sciences 41 (2010b): 90-98.

Carlin, Martha. "Parron, William ( $b$. before $1461, d$. in or after 1503)." Oxford Dictionary of National Biography, Oxford, 2004.

Carlson, David R. "Politicizing Tudor Court Literature: Gaguin's Embassy and Henry VIII's Humanists' Response." Studies in Philosophy 85 (1988): 279-304.

- "Royal Tutors in the Reign of Henry VII." Sixteenth Century Journal 22.2 (1991): 253-79.

Charmasson, Thérèse. Recherches sur une technique divinatoire: la géomancie dans l'Occident médiéval. Geneva, 1980. 
Chrimes, Stanley Bertram. Lancastrians, Yorkists and Henry VII. $2^{\text {nd }}$ ed., London, 1966. . Henry VII. London, 1972.

Clark, Andrew, ed. Anthony Wood: Survey of the Antiquities of the City of Oxford. 3 vols. Oxford, 1889.

Curley, Michael. "The Cloak of Anonymity and the Prophecy of John of Bridlington." Modern Philology 77 (1980): 361-69.

. "Fifteenth-Century Glosses on the Prophecy of John of Bridlington: A Text, Its Meaning and Its Purpose." Mediaeval Studies 46 (1984): 32139.

Currin, John M. “To Play at Peace: Henry VII, War against France, and the Chieregato-Flores Mediatio of 1490." Albion 31 (1999): 207-37. - "'The King's Army into the Partes of Bretaigne': Henry VII and the Breton Wars, 1489-1491." War in History 7 (2000): 379-412.

. "'To Traffic with War'? Henry VII and the French Campaign of 1492." In The English Experience in France c. 1450-1558: War, Diplomacy, and Cultural Exchange, ed. David Grummitt, 106-31. Aldershot, 2002.

Curry, Patrick. Prophecy and Power: Astrology in Early Modern England. Cambridge, 1989.

Dante Alighieri. The Divine Comedy. Trans. Charles S. Singleton. 2 vols. Princeton, 1970.

Dobrzycki, Jerzy, and Richard L. Kremer. "Peurbach and Maragha Astronomy? The Ephemerides of Johannes Angelus and Their Implications." Journal for the History of Astronomy 27 (1996): 187-237.

Dykes, Benjamin, trans. Guido Bonatti: Book of Astronomy [in Ten Books]. Golden Valley, MN, 2008.

Eade, J. C. The Forgotten Sky: A Guide to Astrology in English Literature. Oxford, 1984.
Edwards, H. L. R. "Robert Gaguin and the English Poets, 1489-90." Modern Language Review 32.3 (1937): 43034.

Erasmus, Desiderius. Opus Epistolarum Des. Erasmi Roterdami. Ed. P. S. Allen, H. M. Allen, and H. W. Garrod. 12 vols. Oxford, 1922.

Fletcher, Doris. "The Lancastrian Collar of Esses: Its Origins and Transformations Down the Centuries." In The Age of Richard II, ed. James L. Gillespie, 191-204. Stroud, 1997.

Forshall, Josiah. Catalogue of Manuscripts in the British Museum: New Series. Pt. 1 the Arundel Manuscripts - Pt. 2. The Burney Manuscripts. London, 1834.

Fox-Davies, Arthur Charles. A Complete Guide to Heraldry. London, 1909.

Freeman, Jessica. "Sorcery at Court and Manor: Margery Jourdemayne, the Witch of Eye Next Westminster." Journal of Medieval History 30.4 (2004): 343-57.

Garin, Eugenio. Astrology in the Renaissance: The Zodiac of Life. Trans. Carolyn Jackson, June Allen, and Clare Robertson. London, 1983.

Grafton, Anthony. Cardano's Cosmos: The Worlds and Works of a Renaissance Astrologer. Cambridge, MA, 1999.

Griffiths, Ralph Alan. "The Trial of Eleanor Cobham: An Episode in the Fall of Duke Humphrey of Gloucester." Bulletin of the John Rylands Library 51 (1968-69): 381-99.

Gunn, Steven J. "The Courtiers of Henry VII." English Historical Review 108 (1993): 23-49.

—. "Henry VII (1457-1509)." Oxford Dictionary of National Biography. Oxford, 2004.

Gutas, Dmitri. Greek Thought, Arabic Culture: The Graeco-Arabic Translation Movement in Baghdad and Early 'Abbāsid society $\left(2^{\text {nd }}-4^{\text {th }} / 8^{\text {th }}-10^{\text {th }}\right.$ Centuries). London, 1998. 
Hammer, Jacob. "A Commentary on the Prophetia Merlini (Geoffrey of Monmouth's Historia Regum Britanniae, Book VII) [pt. 1]." Speculum 10 (1935): 3-30.

. "A Commentary on the Prophetia Merlini (Geoffrey of Monmouth's Historia Regum Britanniae, Book VII) [pt. 2]." Speculum 15 (1940): 409-31.

Hoak, Dale. "The Iconography of the Crown Imperial." In Tudor Political Culture, ed. Dale Hoak, 54-103. Cambridge, 1995.

Holloway, Julia Bolton. Saint Bride and Her Book: St. Birgitta's Revelations. Cambridge, 2000.

Hughes, Jonathan. Arthurian Myths and Alchemy: The Kingship of Edward IV. Stroud, 2002.

Jefferson, Lisa. "Edward III's Horoscope in a Stained-Glass Window." Friends Report (1991-92): 95-102.

Johnston, Hope. "Catherine of Aragon's Pomegranate, Revisited." Transactions of the Cambridge Bibliographical Society 12 (2005): 153-73.

Jones, W. R. "Political Uses of Sorcery in Medieval Europe." The Historian 34 (1972): 670-87.

Kanas, Nick. Star Maps: History, Artistry, and Cartography. Chichester, 2007.

Kibre, Pearl. "The Intellectual Interests Reflected in Libraries of the Fourteenth and Fifteenth Centuries." Journal of the History of Ideas 7.4 (1946): 257-97.

-. "Lewis of Caerleon, Doctor of Medicine, Astronomer, and Mathematician (d. 1494?)." Isis 43 (1952): 100-08.

Kipling, Gordon. The Triumph of Honour: Burgundian Origins of the Elizabethan Renaissance. Leiden, 1977.

. "Henry VII and the Origins of Tudor Patronage." In Patronage in the Renaissance, ed. Guy Fitch Lytle and Stephen Orgel, 117-64. Princeton, 1981.
Kren, Thomas, and Scot McKendrick. Illuminating the Renaissance: The Triumph of Flemish Manuscript Painting in Europe. Los Angeles, 2003.

Leader, Damian Riehl. A History of the University of Cambridge, Vol. 1: The University to 1546.4 vols. Cambridge, 1988.

Lippincott, Kristen. "The Astrological Vault of the Camera di Griselda from Roccabianca." Journal of the Warburg and Courtauld Institute 48 (1985): 42-70.

- "Two Astrological Ceilings Reconsidered: The Sala di Galatea in the Villa Farnesina and the Sala del Mappamondo at Caprarola." Journal of the Warburg and Courtauld Institute 53 (1990): 185-207.

[London Pageants for the Entry of Katherine of Aragon into the City of London, 1501.] In The Antiquarian Repertory, ed. Francis Grose and Thomas Astle, 2:248-89. London, 1808.

Maddison, Francis, Margaret Pelling, and Charles Webster, eds. Linacre Studies: Essays on the Life and Work of Thomas Linacre, c. 1460-1524. Oxford, 1977.

Marks, Richard, and Paul Williamson. Gothic: Art for England, 1400-1547. London, 2003.

Mayvaert, Paul. "John Erghome and the Vaticinium Roberti Bridlington." Speculum 41 (1966): 656-64.

McConica, James. "Erasmus, Desiderius (c. 1467-1536)." Oxford Dictionary of National Biography. Oxford, 2004.

McKendrick, Scot. Flemish Illuminated Manuscripts 1400-1550. London, 2003.

McKendrick, Scot, John Lowden, and Kathleen Doyle. Royal Manuscripts: The Genius of Illumination. London, 2012.

North, J. D. "The Alfonsine Tables in England." In Stars, Minds and Fate: 
Essays in Ancient and Medieval Cosmology, 327-60. London, 1989. . "Killingworth, John (d. 1445)." Oxford Dictionary of National Biography. Oxford, 2004.

Page, Sophie. "Richard Trewythian and the Uses of Astrology in Late Medieval England." Journal of the Warburg and Courtauld Institute 64 (2001): 193-228.

- Astrology in Medieval Manuscripts. London, 2002.

Papworth, John W. An Alphabetical Dictionary of Coats of Arms. 1874. Baltimore, 1965.

Parron, William. Pronosticon libellus. London, 1499.

Pronosticon libellus. London, 1501.

Pattie, T. S. Astrology: As Illustrated in the Collections of the British Library and the British Museum. London, 1980.

Penn, Thomas. Winter King: The Dawn of Tudor England. London, 2011.

Plomer, Henry R. "Bibliographical Notes from the Privy Purse Expenses of King Henry VII." The Library, ser. 3, 4.15 (1913): 291-305.

Quinlan-McGrath, Mary. "The Astrological Vault of the Villa Farnesina: Agostino Chigi's Rising Sign." Journal of the Warburg and Courtauld Institute 47 (1984): 91-105. ."The Villa Farnesina, TimeTelling Conventions and Renaissance Astrological Practice." Journal of the Warburg and Courtauld Institute 58 (1995): 52-71.

- "The Foundation Horoscope(s) for St. Peter's Basilica, Rome, 1506." Isis 92.4 (2001): 716-41.

Ralley, Robert Charles. "The Clerical Physician in Late Medieval England." $\mathrm{PhD}$ diss., University of Cambridge, 2005.

-. "Stars, Demons and the Body in Fifteenth-century England." Studies in the History and Philosophy of Science Part C 41 (2010): 109-16.
Rāshid, Rushdī, and Régis Morelon, eds. Encyclopedia of the History of Arabic Science, vol. 1. London, 1996.

Reeve, Michael D., ed. Geoffrey of Monmouth: The History of the Kings of Britain: An Edition and Translation of De Gestis Britonum (Historia Regum Britanniae). Trans. Neil Wright. Woodbridge, 2007.

Regiomontanus. Ephemerides, 1475-1506. Nuremberg, 1474.

Rigg, A. G. "John of Bridlington's Prophecy: A New Look.” Speculum 63 (1988): 596-613.

Rundle, David. "On the Difference between Virtue and Weiss: Humanist Texts in England During the Fifteenth Century." In Courts, Courtiers and the Capital in the Later Middle Ages, ed. D. E. S. Dunn, 181-203. New York, 1996.

. "Filippo Alberici, Henry VII and Richard Fox: The English Fortunes of a Little-Known Humanist." Journal of the Warburg and Courtauld Institutes 68 (2005): 137-55.

Saxl, Fritz, Hans Meier, and Harry Bober. Verzeichnis Astrologischer und Mythologischer Illustrierter Handschriften des Lateinischen Mittelalters. III, Handschriften in Englischen Bibliotheken. 2 vols. London, 1953.

Scott, Kathleen L. Later Gothic Manuscripts, 1390-1490. A Survey of Manuscripts Illuminated in the British Isles. 2 vols. London, 1996.

—_. Dated and Datable English Manuscript Borders: c. 1395-1499. London, 2002.

. "Manuscripts for Henry VII, His Household and Family." In The Cambridge Illuminations: The Conference Papers, ed. Stella Panayotova, 279-86. London, 2007.

Smith, Gill. Understanding Blazons. http://www.apl385.com/gilling/blazon. htm (accessed 21 March 2012). 
Smoller, Laura Ackerman. History, Prophecy, and the Stars: The Christian Astrology of Pierre d'Ailly. Princeton, 1994.

Snedegar, Keith. "Caerleon, Lewis (d. in or after 1495)." Oxford Dictionary of National Biography. Oxford, 2001.

Starkey, David. "King Henry and King Arthur." Arthurian Literature 16 (1998): 171-96.

Stratford, Jenny, and Teresa Webber. "Bishops and Kings: Private Book Collections in Medieval England. In Cambridge History of Libraries in Britain and England, 178-217. 3 vols. Cambridge, 2006.

Thorndike, Lynn. A History of Magic and Experimental Science. 8 vols. New York, 1923-58.

Thorndike, Lynn, and Pearl Kibre. $A$ Catalogue of Incipits of Mediaeval Scientific Writings in Latin. London, 1963.

Vanden Broecke, Steven. The Limits of Influence: Pico, Louvain, and the Crisis of Renaissance Astrology. Leiden, 2003.

Veenstra, J. R. Magic and Divination at the Courts of Burgundy and France. Texts and Contexts of Laurent Pignon: Contre les devineurs (1411). Leiden, 1997.

Walden, Howard de. Banners, Standards, and Badges from a Tudor Manuscript. London, 1904.

Ward, H. L. D. Catalogue of Romances in the Department of Manuscripts in the British Museum. London, 1883.

Warner, George F., and Julius P. Gilson. Catalogue of Western Manuscripts in the Old Royal and King's Collections. 3 vols. London, 1921.
Watson, Andrew G. Medieval Manuscripts in Post-Medieval England. Aldershot, 2004.

Wayment, Hilary G. "The Medieval Stained Glass." In A History of the Stained Glass of St George's Chapel, Windsor Castle, ed. Sarah Brown, 1-64. Windsor, 2005.

Wedel, T. O. The Medieval Attitude toward Astrology, Particularly in England. New Haven, 1920.

Whitfield, Peter. The Mapping of the Heavens. London, 1995.

- Astrology: A History. Boston Spa, 2001.

Wickersheimer, Ernest, and Simon de Phares. Recueil des plus celebres astrologues et quelques homes doctes. Paris, 1929.

Winn, Mary Beth. Anthoine Vérard, Parisian Publisher, 1485-1512. Geneva, 1997.

Woolfson, Jonathan. Padua and the Tudors: English Students in Italy 1485-1603. Cambridge, 1998.

Wright, Thomas. "Satire on the Political Acts of Edward III by John of Bridlington, Especially from 13271346." In Political Poems and Songs Relating to English History, 123-215. London, 1859.

Yale University, Online Catalogue, Beinecke Rare Book and Manuscript Library, http://brbl-net.library.yale.edu/pre1600ms/ docs/pre1600.mell025.HTM (accessed 29 September 2011).

Zuffi, Stefano, and Alessandro Novellone. Arte \& Zodiaco. Storia, misteri e interpretazione dei segni zodiacili nei secoli. Rome, 2009. 
Copyright of Renaissance Quarterly is the property of University of Chicago Press and its content may not be copied or emailed to multiple sites or posted to a listserv without the copyright holder's express written permission. However, users may print, download, or email articles for individual use. 